\title{
USO DE SUBPRODUTOS AGROINDUSTRIAIS PARA SUPLEMENTAÇÃO DE NOVILHOS EM TERMINAÇÃO DURANTE O PERIODO DE SECAS
}

\section{ANDRÉ ALVES DE SOUZA \\ Médico Veterinário}

Orientador: Prof. Dr. CELSO BOIN

\begin{abstract}
Dissertação apresentada à Escola Superior de Agricultura "Luiz de Queiroz", Universidade de São Paulo, para obtenção do título de Mestre em Agronomia, Área de Concentração: Ciência Animal e Pastagens.
\end{abstract}

PIRACICABA

Estado de São Paulo - Brasil Janeiro - 2002 


\section{Errata}

Autor: André Alves de Souza

USO DE SUBPRODUTOS AGROINDUSTRIAIS PARA SUPLEMENTAÇÃO DE NOVILHOS EM TERMINAÇÃO DURANTE O PERÍODO DE SECAS

\begin{tabular}{|c|c|c|c|c|}
\hline p. & item & linha & onde se lê & leia-se \\
\hline Xiii & & primeira & $\begin{array}{l}\text { Energetic-proteic } \\
\text { supplementation }\end{array}$ & Protein supplementaion \\
\hline Xiv & & $\begin{array}{l}\text { Décima } \\
\text { sétima }\end{array}$ & $\begin{array}{l}\text { Energetic-proteic } \\
\text { supplementation }\end{array}$ & Protein supplementaion \\
\hline Xiii & & terceira & $\begin{array}{l}0,3 ; 0,6 \text { and } 0,7 \% \text { of } \\
\text { livewheight }\end{array}$ & $\begin{array}{l}0.3 ; 0.6 \text { and } 0.7 \% \text { of } \\
\text { liveweight }\end{array}$ \\
\hline 7 & 2.1 & oitava & $0,2.5,5$ e $7.5 \%$ PB & $0,2,5,5$ e $7,5 \%$ \\
\hline 36 & 3.14 & segunda & Tabela 5 & Tabela 4 \\
\hline 7 & 4.1 & sexta & (Tabela 1 e Figura 2) & (Tabela 5 e Figura 2 ) \\
\hline
\end{tabular}

53 4.7.1 Tabela 17. Espessura de gordura de cobertura avaliada através de ultra-sonografia nos diferentes tratamentos.

Tratamentos EG ultra-som $(\mathrm{mm}) \quad$ EGultr/100 Kg carcaça $(\mathrm{mm})$

$\begin{array}{lcr}\text { Controle } & 3,76^{\mathrm{a}}+0,28 & 1,53^{\mathrm{a}}+0,22 \\ \text { Leucena } & 4,04^{\mathrm{a}}+0,30 & 1,52^{\mathrm{a}}+0,12 \\ \text { Supl.1 } & 3,70^{\mathrm{a}}+0,25 & 1,32^{\mathrm{a}}+0,09 \\ \text { Supl.2 } & 4,02^{\mathrm{a}}+0,34 & 1,46^{\mathrm{a}}+0,13 \\ \text { * Valores seguidos de letras diferentes diferem estatisticamente }(P<0,05) & \end{array}$




\section{Dados Internacionais de Catalogaçāo na Publicaçāo (CIP) DIVISÃO DE BIBLIOTECA E DOCUMENTAÇÃO - ESALQ/USP}

\section{Souza, André Alves}

Uso de subprodutos agroindustriais para suplementação de novilhos em terminação durante o periodo de secas / André Alves de Souza. - - Piracicaba, 2002.

$71 \mathrm{p}$.

Dissertação (mestrado) - - Escola Superior de Agricultura Luiz de Queiroz, 2002. Bibliografía.

1. Seca 2. Subprodutos para animais 3. Suplementos alimentares para animais I. Título

CDD 636.2085 


\section{Dedicatória}

A toda minha família pela efetiva participação na realização de mais essa etapa da minha vida...

DEDICO 


\section{Agradecimentos}

Ao meu orientador Prof. Dr. Celso Boin, pela confiança em min depositada e as orientações na condução do trabalho

Ao Instituto de Zootecnia, em especial ao pesquisador científico $\mathrm{Dr}$. Antônio João Lourenço, pela concessão da área experimental e o apoio e orientação durante a execução do experimento.

Aos funcionários do Instituto de Zootecnia: Sr. José Camargo, Sr. Geraldo, Sr. Avelino e Sr. Diógenes (in memorian), pelo apoio durante todo periodo experimental.

Ao Prof. Dr. Paulo Henrique Mazza Rodrigues e ao amigo Marco Antônio Sundfeld da Gama, pela colaboração nas análises estatísticas.

A colega Carla Maris Bittar Nussio, pela fundamental ajuda e paciência durante a execução dos procedimentos laboratoriais.

A todos os colegas que, direta ou indiretamente, ajudaram para a realização desse projeto.

A Fundação de amparo à pesquisa do estado de São Paulo FAPESP, pela concessão de bolsa de estudos e apoio financeiro para o desenvolvimento do experimento. 


\section{Sumário}

Página

LISTA DE FIGURAS............................................................. viii

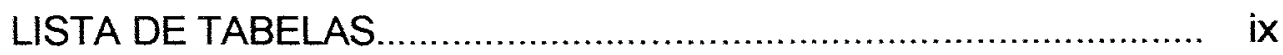

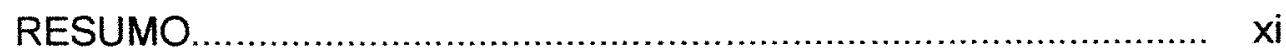

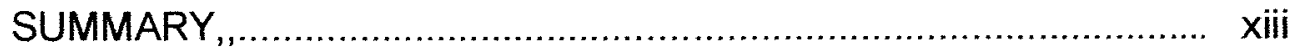

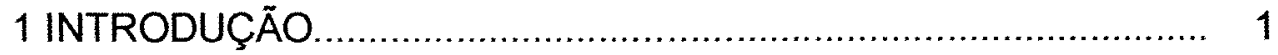

2 REVISÃO DE LITERATURA ................................................. 3

2.1 Suplementação protéica......................................................... 4

2.1.1 Leucaena leucocephala....................................................... 9

2.2 Suplementação energética.................................................... 10

2.3 Efeito de substituição ............................................................ 13

2.4 Refinazil ${ }^{(}$(corn gluten feed)................................................. 14

2.4.1 Moagem úmida do milho................................................ 15

2.5 Polpa citrica peletizada......................................................... 19

2.6 Efeito da suplementação sobre os parâmetros ruminais............. 20

2.6.1 Ácidos graxos voláteis (AGV'S) ........................................ 20

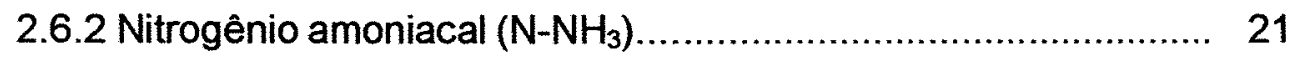

2.7 Efeito da suplementação sobre os parâmetros sanguíneos......... 23

2.7.1 Uréia sérica..................................................................... 23

2.8 Qualidade de came .............................................................. 23

2.8.1 Espessura de gordura de cobertura....................................... 25

2.8.2 Área de olho de lombo....................................................... 26

3 MATERIAL E MÉTODOS........................................................ 27 
3.1 Local e duração............................................................. 27

3.2 Área experimental...................................................... 27

3.3 Pastagem e manejo ......................................................... 27

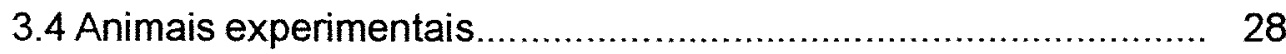

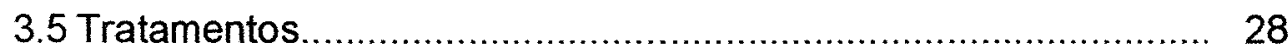

3.6 Suplementação mineral e alimentar........................................ 29

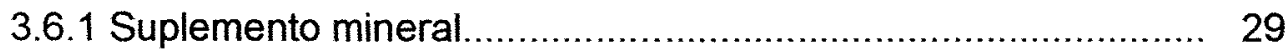

3.6.2 Suplemento alimentar............................................... 29

3.6.3 Caracterização do refinazil úmido ${ }^{\circledR}$ e polpa cítrica peletizada... 30

3.6.4 Polpa cítrica peletizada................................................... 30

3.7 Pesagem dos Animais........................................................ 31

3.8 Avaliação da forragem disponível.......................................... 31

3.9 Coleta de amostras............................................................ 32

3.10 Determinações no líquido ruminal......................................... 33

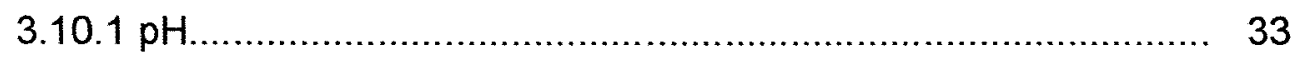

3.10.2 Ácidos Graxos Voláteis.................................................. 33

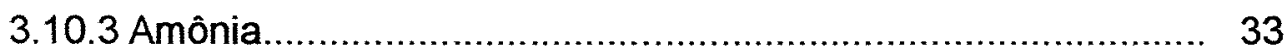

3.11 Determinações sanguíneas.................................................. 34

3.12 Determinação da espessura de gordura de cobertura (EG)...... 35

3.13 Determinação da área de olho de lombo (AOL)...................... 35

3.14 Análise Estatística............................................................ 35

4 RESULTADOS E DISCUSSĀO............................................ 37

4.1 Disponibilidade e qualidade da forragem................................. 37

4.2 Composição dos suplementos fornecidos................................... 41

4.3 Parâmetros ruminais....................................................... 42

4.3.1 Ácidos Graxos Voláteis .................................................... 42

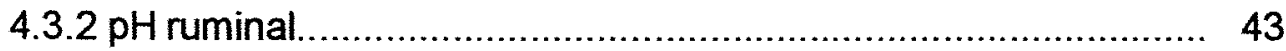

4.3.3 Concentrações de amônia ruminal......................................... 44

4.4 Parâmetros sanguíneos........................................................ 45

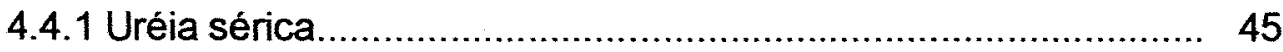

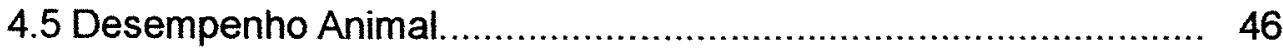

4.6 Avaliações de carcaça.............................................................. 51 
4.6.1 Rendimento de carcaça........................................... 51

4.6.2 Espessura de gordura de cobertura após resfriamento (EG)... 52

4.7 Avaliações através de ultra-sonografia................................. 53

4.7.1 Espessura de gordura de cobertura (EGultr)..................... 53

4.7.2 Área de olho de lombo (AOL) ..................................... 55

5 CONCLUSÖES.............................................................. 57

REFERÊNCIAS BIBLIOGRÁFICAS...................................... 58 


\section{LISTA DE FIGURAS}

Página

1 Esquema de obtenção dos subprodutos do milho

2 Disponibilidades médias de forragem dentro dos diferentes

tratamentos durante todo o periodo experimental.

3 Ganhos médios diários e teores de PB nos diferentes períodos experimentais para os diferentes tratamentos

4 Desempenho de bovinos Nelore em terminação com diferentes suplementos alimentares

5 Peso vivo final de bovinos Nelore em terminação com diferentes suplementos alimentares

6 Produção por área de bovinos Nelore em terminação com diferentes suplementos alimentares

7 Correlação entre os valores de espessura de gordura avaliados através de ultra-sonografia in vivo e medida direta na carcaça na altura da $12^{\mathrm{a}}$ costela após resfriamento. 


\section{LISTA DE TABELAS}

Página

1 Especificações físico-quimicas garantidas do refinazil ${ }^{\circledR}$ seco............ 18

2 Composição química do refinazil ${ }^{\circledR}$ úmido........................................ $\quad 30$

3 Composição química e conteúdo de energia bruta da polpa

cítrica peletizada de origem brasileira ............................................ 31

4 Esquema de análise de ariância.................................................. 36

5 Disponibilidade, matéria seca, proteína bruta, fibra em detergente ácido, fibra em detergente neutro e lignina nos diferentes tratamentos durante o período experimental.

6 Proteína bruta e digestibilidade "in vitro" da leguminosa (Leucaena leucocephala)

7 Dados meteorológicos mensais coletados no Instituto de Zootecnia Nova Odessa/SP durante o ano de 2000

8 Composição bromatológica dos suplementos alimentares

fornecidos nos diferentes tratamentos.

9 Concentração dos AGV'S nos diferentes tratamentos

10 Valores de $\mathrm{pH}$ ruminal para os diferentes tratamentos.

11 Concentração de amônia no líquido ruminal dos diferentes

tratamentos.

12 Concentrações sanguíneas de uréia nos diferentes tratamentos...

13 Ganhos médios diários durante todo periodo experimental para os diferentes tratamentos.

14 Ganhos médios diários nos diferentes periodos experimentais para os diferentes tratamentos 
15 Avaliações nas carcaças e porcentagem de animais abatidos nos diferentes tratamentos..

16 Espessura de gordura de cobertura de bovinos em terminação com diferentes suplementos.

17 Espessura de gordura de cobertura avaliada através de ultrasonografia nos diferentes tratamentos.

18 Área de olho de lombo de bovinos em terminação com diferentes suplementos alimentares. 


\title{
USO DE SUBPRODUTOS AGROINDUSTRIAIS PARA SUPLEMENTAÇÃO DE NOVILHOS DURANTE O PERIODO DE SECAS
}

\author{
Autor: ANDRÉ ALVES DE SOUZA \\ Orientador: Prof. Dr. CELSO BOIN
}

\section{RESUMO}

Foram avaliados os efeitos da suplementação energético-protéico sobre o desempenho, fermentação ruminal, uréia plasmática e características de carcaça de bovinos Nelore em terminação a pasto. Utilizaram-se 128 animais divididos em quatro tratamentos com quatro repetições, sendo 32 animais em cada tratamento. $O$ delineamento experimental foi de blocos inteiramente casualizados. Os tratamentos foram: Controle $=$ Pastagem de Brachiaria brizanta cv. marandu + suplemento mineral; Leucena $=$ Pastagem de Brachiaria brizanta cv. marandu + Banco de proteína (Leucaena leucocephala) $+2 \mathrm{Kg}$ polpa cítrica peletizada $+2 \mathrm{Kg}$ refinazil úmido ${ }^{(1)}$ suplemento mineral (animal/dia); Supl.1 = Pastagem de Brachiaria brizanta $\mathrm{cv}$. marandu $+2 \mathrm{Kg}$ polpa cítrica peletizada $+2 \mathrm{Kg}$ refinazil úmido ${ }^{\circledast}+0.5 \mathrm{Kg}$ farelo de soja $+0.1 \mathrm{Kg}$ uréia + suplemento mineral (animal/dia); Supl.2 = Pastagem de Brachiaria brizanta cv. marandu $+2 \mathrm{Kg}$ 
polpa cítrica peletizada $+2 \mathrm{Kg}$ refinazil ${ }^{\circledR}$ úmido $+1 \mathrm{Kg}$ farelo de soja $+0.1 \mathrm{Kg}$ uréia + suplemento mineral (animal/dia). A utilização de suplementos alimentares na proporção de $0,3,0,6$ ou $0,7 \%$ do peso vivo, não alterou as caracteristicas fermentativas ruminais de bovinos Nelore em terminação. A suplementação proporcionou melhor desempenho $(P \leq 0,05)$ aos animais suplementados em relação aos não suplementados e leucena, quando se avaliou o periodo total. Houve interação tempo $x$ tratamento, sendo que no primeiro período houveram maiores ganhos $(P \leq 0,05)$ para os tratamentos Supl.1 e 2 em relação ao leucena e controle. No segundo e terceiro periodos as diferenças em desempenho foram estatisticamente superiores $(P \leq 0,05)$ para os tratamentos leucena, Supl. 1 e 2, em relação ao grupo controle, sem haver diferença estatística entre os suplementos. Não houve diferença entre os quatro tratamentos no quarto período experimental (outubro), devido ao início das chuvas e aumento da quantidade e qualidade da forragem. No último periodo ocorreram menores ganhos para o controle e Supl.2 em relação ao Supl.1 e leucena. Em relação às características de carcaça, foram detectados maiores rendimentos de carcaça $(P \leq 0,05)$ para os animais suplementados em relação ao grupo controle. As medidas de espessura de gordura também foram maiores $(P \leq 0,05)$ para os animais suplementados, não havendo diferença estatística $(P \leq 0,05)$ quando os valores foram relacionados a $100 \mathrm{Kg}$ de carcaça. Não foi observada diferença estatística nos valores absolutos de área de olho de lombo. Porém quando relacionados a $100 \mathrm{Kg}$ de carcaça, observou-se maiores valores $(P \leq 0,05)$ para os animais controle. A suplementação energético-protéica de bovinos Nelore terminados a pasto permite a diminuição da idade de abate devido ao aumento da velocidade de crescimento. 


\title{
THE USE OF BYPRODUCTS IN SUPPLEMENTATION OF FINISHING STEERS DURING DRY SEASON.
}

\author{
Author: ANDRÉ ALVES DE SOUZA \\ Adviser: Prof. Dr. CELSO BOIN
}

\section{Summary}

This study has evaluated the effects of energetic-proteic supplementation in animal performance, ruminal fermentation, plasma urea and carcass characteristics of Nellore cattle in pasture. A hundred and twenty eight animals have been evaluated. The statistical design has been a randomized block with four treatments and four replications.

The treatments were: Control $=$ Brachiaria brizanta + mineral supplement; Leucena = Brachiaria brizanta + protein bank (Leucaena leucocephala) $+2 \mathrm{Kg}$ citrus pulp $+2 \mathrm{Kg}$ Wet corn gluten feed + mineral supplement (animal/day); Supl1 $==$ Brachiaria brizanta pasture $+2 \mathrm{Kg}$ citrus pulp $+2 \mathrm{Kg}$ Wet corn gluten feed $+0,5 \mathrm{Kg}$ soybean meal + mineral supplement (animal/day); Supl2 $=$ Brachiaria brizanta pasture $+2 \mathrm{Kg}$ citrus 
pulp $+2 \mathrm{Kg} \mathrm{Wet} \mathrm{corn} \mathrm{gluten} \mathrm{feed}+1 \mathrm{Kg}$ soybean meal + mineral supplement (animal/day).

Supplementation with 0,$3 ; 0,6$ and $0,7 \%$ of livewheight hasn't altered the fermentative characteristics of the rumen. The supplementation provides higher daily weight gain to the supplemented animals for the total experimental period. We have noticed interaction time $x$ treatment and in the first period higher gains for the Supl1 e 2 have been observed. In the second and third periods, the gains have been higher for leucena, Supl1 e 2. There was no difference in daily gain for all treatments in the fourth experimental period, probably because the initial rains and consequently higher quality and disponibility of the forage. In the final period, the supplements leucena and Supl1 have been higher than control and Supl.2.

It has been observed higher carcass yield for the supplemented animals of the treatments leucena, Supl. 1 e 2 . The results of backfat have been like the yield carcass results, but when the values of backfat were related with $100 \mathrm{Kg}$ of carcass, no difference have been observed.

The energetic-proteic supplementation provides the reduction of the age of slaughter, because it elevates in growth velocity. 


\section{INTRODUÇÃO}

A produção de gado de corte baseada em pastagens nos trópicos apresenta uma característica marcante na curva de crescimento dos animais, com períodos de ganho de peso satisfatórios, intercalados por períodos de baixo desempenho ou perda de peso. Esses diferentes períodos de crescimento dos bovinos em pastejo estão intimamente relacionados à estacionalidade e crescimento das plantas forrageiras. Aproximadamente 70 a $80 \%$ da produção anual das forrageiras tropicais, concentra-se nos meses de maiores índices pluviométricos, produzindo somente $20 \%$ no periodo de secas. O baixo desempenho dos animais nas estações secas, leva ao aumento da idade de abate e conseqüentemente queda na qualidade da carne produzida. No caso de fêmeas, os períodos de baixo desempenho aumentam a idade à primeira cobertura.

Assim sendo, a flutuação na oferta de alimentos para os animais mantidos a pasto é fator limitante, refletindo-se na produção animal levando a menores indices zootécnicos.

Cerca de $80 \%$ do rebanho nacional está abrigado em regime de pastejo, sendo que a Brachiaria spp. perfaz aproximadamente $70 \%$ das áreas de pastagens (Lourenço \& Carriel 1997). Portanto, a bovinocultura de corte brasileira deverá estabelecer sistemas como o de suplementação a pasto, semiconfinamento ou confinamento estratégico, capazes de produzir carne de boa qualidade a baixo custo, abatendo animais com menos de 36 meses de idade. Essas mudanças estão sendo muito estimuladas, devido aos problemas sanitários ocorridos na Europa, com conseqüente tendência de melhora nas 
exportações, que proporcionam melhores rentabilidades à atividade pecuária, porém exigem padronização e qualidade das carcaças.

O consumidor do mercado interno atual prefere carnes bovinas mais macias, com pouca gordura e a preços competitivos com as carnes de suíno e aves. Para poder competir por preço, a cadeia produtiva da carne bovina deverá aumentar sua produtividade, diminuindo a diferença na eficiência produtiva, devido à melhor conversão alimentar de aves e suínos em relação aos ruminantes.

Os sistemas de produção de bovinos em pastagens têm condições de conseguir um produto com as caracteristicas citadas acima, desde que, utilizando suplementação alimentar nos períodos em que a forrageira não forneça os nutrientes necessários para satisfazer as exigências dos animais.

Segundo Griebenow, et al., (1997), sistemas de terminação de bovinos de corte baseados exclusivamente em pastagens sem a utilização de grãos na terminação, não apresentam resultados satisfatórios em relação à qualidade da carne produzida.

Além disso, a redução da idade de abate e o início da atividade reprodutiva, são pontos fundamentais para aumento da taxa de desfrute dos rebanhos de corte.

Dentro das situações e perspectivas citadas acima, o presente trabalho avaliou a influência da suplementação sobre o ganho de peso, as características ruminais e a concentração de uréia sanguínea, redução da idade de abate e a melhora na qualidade de carne de bovinos em terminação a pasto, suplementados com subprodutos agroindustriais. 


\section{REVISÃO DE LITERATURA}

O ganho de peso depende principalmente do suprimento de aminoácidos e de substratos energéticos para os tecidos, considerando que o limite genético para síntese protéica, dificilmente seria alcançado pelos animais em pastejo (Poppi \& Mclennan, 1995). O suprimento de aminoácidos está relacionado ao conteúdo protéico da dieta, da sua transferência na forma de proteína não degradável e microbiana, e da absorção destas no intestino delgado. Por outro lado, a deposição protéica depende da eficiência do uso da proteína absorvida, que é função da disponibilidade de substratos energéticos e de aminoácidos essenciais limitantes.

Pesquisas foram conduzidas com o objetivo de reduzir a significativa perda de peso que ocorre durante o período de baixa produtividade forrageira, seja fornecendo fontes de nitrogênio não protéico (Pate et al., 1995), ou suplementando com alimentos alternativos (Winter et al., 1991).

A adoção de fontes de nitrogênio não protéica, como a uréia, associadas às misturas minerais, é a forma mais freqüentemente utilizada para eliminar a deficiência protéica durante o período seco.

A suplementação protéica de animais em pastejo durante o período de secas elimina as fases negativas do crescimento (Grings, et al., 1997; Willms et al., 1997; Pate et al., 1995; Winter et al., 1991; Euclides et al. 1997; Haddad \& Castro, 1998; Euclides et al. 1998; Vieira \& Peixoto, 1976). Essa suplementação pode ser feita através da associação de leguminosas (Ex.: Leucaena leucocephala) na forma de banco de proteína (Lourenço, 1993; Hernandes et al., 1992). 
A suplementação a pasto tem grande influência na produção de carne, pois além de reduzir a idade de abate, diminui o custo fixo e permite maior velocidade no giro de capital (Euclides et al. 1998).

Euclides et al. (1997) observaram ganhos médios de 514g/animal/dia, e idade média ao abate de 23,6 meses, quando os animais foram suplementados na primeira e segunda secas.

A suplementação protéica e/ou energética de animais em pastejo durante o período de pleno crescimento forrageiro é questão mais recente e alguns resultados apontam no sentido de desenvolvimento de uma nova forma de manejo nutricional dos ruminantes.

Winter et al. (1991), ao revisar os índices de ganho de peso médio na Austrália, durante o período das águas, encontrou valores não superiores a $700 \mathrm{~g}$ por dia. Dados semelhantes são observados nas condições de produção do Brasil Central. Por outro lado, para as regiões temperadas são observados ganhos diários maiores, ainda que parte destas diferenças possa ser atribuída aos diferentes potenciais zootécnicos das raças criadas nessas regiōes. Os aspectos nutricionais, relacionados às características das plantas forrageiras tropicais e temperadas, explicam também os resultados obtidos.

As caracteristicas histológicas, físicas e químicas das plantas forrageiras são em parte responsáveis pelas diferenças quanto aos potenciais de digestibilidade e de consumo de forragem (Poppi \& Mclennan, 1995).

\subsection{Suplementação protẽica}

A suplementação protéica de animais em pastejo é uma ferramenta que permite corrigir dietas desbalanceadas, melhorando o ganho de peso vivo, a conversão alimentar, e por conseqüência diminuir os ciclos produtivos da pecuária de corte (Peruchena, 1999).

Poppi ${ }^{1}$ afirma que a habilidade de se alterar a composição corporal dos

${ }^{1}$ citado por Poppi \& Mclennan (1995) 
animais mantidos a pasto depende da obtenção de alta relação energia/proteína, em relação aos nutrientes absorvidos. O simples aumento dos teores protéicos do material ingerido não é uma garantia de maior suprimento intestinal de proteína por unidade de matéria seca ingerida, ou maior quantidade de proteína absorvida. Tal eficiência no aproveitamento da fração protéica dependeria da disponibilidade de energia para os microorganismos ruminais utilizarem a amônia oriunda da proteína degradada.

Acredita-se que em condições de pastagens tropicais, durante o período de secas, ocorra tanto deficiência de proteina degradável no rúmen (PDR), quanto de proteína não degradável no rúmen (PNDR). Com isso, haveria necessidade de adição de fontes de proteína pouco solúveis, quando da suplementação de animais recebendo dietas à base de forragens de baixa qualidade. Porém, as concentrações de PDR devem ser primariamente consideradas na suplementação protéica, para se obter a máxima degradação da forragem no rúmen (Hafley et al., 1993; Ludden, et al. 1995, Bandyk et al., 2001).

Segundo Koster et al., (1996); Mathis et al., (1999); Bodine et al., (2000); Riordan, et al., (2001); Elgersma, et al., (2001), a inclusão de PDR em dietas com forragem de baixa qualidade, melhora a digestibilidade da fibra e aumenta a ingestão de matéria seca diária dos animais. Foram observados melhores resultados no desempenho dos animais com inclusão de PDR, tanto em dietas à base de feno de baixa qualidade (Mathis et al., 1999), como com $79.5 \%$ de milho quebrado (Shain et al., 1998).

Segundo Minson \& Milford (1965) citados por Minson (1990) o nível mínimo de PB na forragem, para que não ocorra diminuição da ingestão voluntária, é de $7 \%$.

Dois problemas devem ser considerados em relação à proteina de forragens tropicais: um seria os baixos teores, o outro a considerável degradabilidade ruminal da mesma. Desta forma deve-se considerar as fontes 
de PNDR como fatores nutricionais limitantes para ruminantes em crescimento sob pastejo (Ramos et al., 1998).

As características de degradação e a qualidade da fonte protéica fornecida aos animais são de extrema importância. A utilização de fontes protéicas de menor degradação ruminal, vão proporcionar maior quantidade de proteína no intestino, mas isso não assegura melhora no desempenho, sendo esse dependente do valor biológico da fonte protéica utilizada. A simples substituição na dieta de PDR por PNDR, poderá causar uma deficiência PDR, afetando os microorganismos ruminais e diminuindo a degradabilidade da porção fibrosa da dieta (Santos et al. 1998).

Albro et al. (1993) ao comparar diversas fontes protéicas (soja integral, soja crua, soja extrusada ou farelo de soja) na suplementação de bovinos consumindo feno, observaram aumento na digestibilidade da matéria seca, e que os ganhos médios diários e a eficiência alimentar, dobraram em relação ao grupo controle, não sendo constatadas diferenças entre as fontes. Porém, nos animais recebendo soja extrusada observaram-se tendências de melhor desempenho, o que provavelmente foi devido as maiores quantidades de PNDR.

Em bovinos de corte pastejando várias espécies de gramíneas, recebendo suplementação protéica com substituição gradativa da fonte protéica degradável no rúmen por fontes protéicas não degradáveis, observou-se aumento linear no ganho de peso diário (Karges et al., 1992). Os autores concluíram, que o ganho de peso adicional promovido pela proteína de baixa degradação ruminal indica que a síntese de proteína microbiana não foi suficiente para satisfazer as exigências em proteína metabolizável.

Em trabalho semelhante, (Ramos et al., 1998) observaram o desempenho de novilhos em crescimento pastejando Cynodon spp. no período das secas, substituindo $100 \%, 50 \%$ e $0 \%$ de uréia, por $0 \%, 50 \%$ e $100 \%$ de fontes protéicas naturais (farinha de sangue, farelo de coco ou farelo de soja). Obtiveram aumentos lineares nos ganhos de peso vivo para suplementos com 
farinha de sangue $(1,11$ e 1,21 $\mathrm{kg} /$ animal/dia) e farelo de coco $(1,05$ e 1,21 $\mathrm{kg} / \mathrm{animal} / \mathrm{dia}$ ), não havendo resposta para os suplementos com farelo de soja (1,01 e 1,00 kg/animal/dia) em relação ao grupo recebendo apenas uréia $(0,97$ $\mathrm{kg} / \mathrm{animal} / \mathrm{dia})$. Concluíram que, animais pastejando forragens de baixa qualidade, eram deficientes em PNDR.

Knaus et al. (1998) trabalhando com novilhos da raça holandesa em gaiolas metabólicas, concluíram que com níveis crescentes de uma mistura balanceada de três fontes, com proporções de 0, 2.5, 5 e $7.5 \%$ da PB em PNDR, houve melhora na digestibilidade, balanço e eficiência da utilização do nitrogênio para bovinos de corte em crescimento. Apesar de não terem obtido diferença estatística para ganho de peso, os autores relataram que a diferença numérica foi de $770 \mathrm{~g} /$ dia para $1315 \mathrm{~g} /$ dia.

Mbongo et al (1994) suplementaram 16 novilhos Belmont Red (272 kg) com quatro níveis de caseína tratada com formaldeído: 0,150, 300 e $500 \mathrm{~g}$ de $\mathrm{PB} /$ dia. Os animais foram mantidos em pastagens de Setaria anceps $(13 \%$ de PB; $63,5 \%$ de FDN) durante 14 semanas e apresentaram ganhos de peso de $862,1112,1030$ e $852 \mathrm{~g}$, respectivamente. As duas melhores respostas representaram um acréscimo de 29 e $19 \%$ sobre o lote controle. Provavelmente, o efeito negativo do mais alto nivel de oferecimento da caseína seja devido ao gasto energético necessário para transformação da amônia em uréia, processo indispensável para eliminação do excesso de nitrogênio nos mamíferos.

Bandyk et al. (2001) avaliaram o efeito da suplementação de PDR ou PNDR, na ingestão e digestão da matéria orgânica de dietas com forragens de baixa qualidade, e observaram que ambas aumentaram a ingestão. Os aumentos foram de 62 e $28 \%$ respectivamente, para PDR e PNDR, em relação ao grupo controle. Os autores concluíram que deve-se priorizar a inclusão de PDR, e o excesso de proteína em relação às exigências dos microorganismos ruminais, passe e seja absorvido no intestino delgado. 
Segundo Poppi \& Mclennan (1995) existem poucas informações sobre o quanto a proteína é limitante no período das águas para forragens de climas tropicais, e que são pouco efetivas as suplementações de forragens de alta qualidade. Porém, ao lançar mão de suplementos com altas quantidades de proteina, pode-se obter melhores respostas em ganho de peso.

Andrade \& Alcalde (1995) citaram trabalhos onde foram utilizadas suplementações de verão com fontes protéicas menos degradáveis no rúmen, como a farinha de carne, com acréscimo de cerca de $300 \mathrm{~g}$ no ganho de peso. Os autores ainda sugeriram, baseando-se em outros trabalhos, a utilização estratégica das fontes de proteína, usando-se fontes menos degradáveis no período das águas e de fontes degradáveis no período das secas.

Ruas et al. (2000), avaliaram a suplementação protéica (40,8\% PB) para vacas de corte durante o período das águas, e observaram aumento na ingestão diária de matéria seca e nos ganhos de peso das fêmeas recebendo suplementação em relação às não suplementadas.

Zervoudakis et al., (2001) utilizando novilhos cruzados e suplementação energético/protéico (20\% PB) à base de milho e farelo de soja ou farelo de trigo e farelo de soja, não observaram diferenças no desempenho dos animais suplementados e não suplementados mantidos em pastagens de Brachiaria decumbens. A falta de resposta à suplementação nesse trabalho provavelmente se deve às altas disponibilidades de forragem e aos níveis de $\mathrm{PB}$, que foram de $7000 \mathrm{Kg} / \mathrm{ha}$ e $9 \% \mathrm{~PB}$, respectivamente. Isso permitiu que os animais selecionassem uma dieta com niveis adequados de nutrientes.

Karn (2000), avaliou o desempenho de novilhos de corte durante cinco anos consecutivos e observou melhores respostas para suplementação energética em relação à suplementação protéica durante o período das águas. O autor citou que, a resposta à suplementação está diretamente relacionada à disponibilidade e qualidade da forragem, e que provavelmente a quantidade de proteína das pastagens atingem os níveis exigidos pelos animais no período das águas. 
Alguns aspectos do suprimento protéico para animais em pastagens no periodo vegetativo, revistos por Poppi \& Mclennan (1995), permitem identificar uma relação entre a transferência da proteína ingerida e a matéria orgânica fermentável no rúmen. As perdas de proteína ou transferência incompleta da proteína dietética para o intestino ocorreriam quando a relação entre teor protéico e matéria orgânica fermentável (MOF) excedesse $210 \mathrm{~g}$ de proteína bruta (PB)/ kg de MOF. O valor de $210 \mathrm{~g}$ de $\mathrm{PB} / \mathrm{kg}$ de MOF poderia ser utilizado para identificar situações nas quais ocorreriam perdas significativas de nitrogênio. Uma relação de $160 \mathrm{~g}$ de $\mathrm{PB} / \mathrm{kg}$ de MOF, já seria o suficiente para ocorrer passagem de proteína para o intestino. Estas relações foram obtidas para pastagens temperadas.

\subsubsection{Leucaena leucocephala}

A limitação mais comum para a produção animal em pastagens nativas é o baixo teor de proteína apresentado pelas mesmas. Desta forma, vários sistemas têm sido desenvolvidos para suplementar ou aumentar a ingestão de proteína pelos animais. Esses sistemas consistem em permitir o acesso dos animais a áreas com leguminosas, as quais são denominadas de "banco de proteína".

A Leucaena leucocephala é uma leguminosa que apresenta elevado potencial de degradação ruminal, disponibilizando rapidamente nutrientes para o sistema ruminal (Veloso, et al. 2000).

Lourenço \& Carriel (1997) observaram ganho de $412 \mathrm{~g} / \mathrm{animal} / \mathrm{dia}$ em animais pastejando $B$. brizantha + Leucaena leucocephala na forma de banco de proteína, sendo superior aos ganhos de braquiária exclusiva, 337 g/animal/dia. Concluíram que a utilização da Leucaena leucocephala na forma de banco de proteína, em pastos de Brachiaria brizantha, pode contribuir para melhorar ganhos diários por animal e por hectare. 
Lourenço et al. (2001) observaram aumentos de 7,7\% no ganho de peso da desmama ao abate, de bovinos Nelore com livre acesso à banco de proteína (Leucaena leucocephala) em relação a pastejo exclusivo de Brachiaria brizantha.

Ruiz et al. (1995), utilizando Pannicun maximum consorciado com leucena, conseguiram ganhos de até 556 g/dia para bovinos em terminação.

Gramíneas tropicais no verão tem digestibilidade entre 55 a $65 \%$ segundo alguns autores, e provavelmente não excedam esse valor, mas muitas leguminosas tropicais podem ultrapassar, levando a passagem de proteína ao intestino. Baseados em diversos trabalhos, o autor observou que o acréscimo de leguminosas na dieta, embora aumente o teor de PB da mesma, não aumentam o suprimento de proteína intestinal por unidade de matéria seca ingerida, ou a relação entre proteína/energia dos produtos absorvidos. Uma exceção é a leucena, cujo tanino presente na planta torna a proteina menos degradável no rúmen, aumentando o fluxo protéico para o intestino (Poppi \& Mclennan, 1995).

Petty et al. (1998) trabalhando com áreas irrigadas de capim pangola e leucena plantada em faixas, no noroeste da Austrália, obtiveram ganho médio diário na estação da seca de $730 \mathrm{~g} / \mathrm{animal} / \mathrm{dia}$, e de $1100 \mathrm{~g} / \mathrm{animal} / \mathrm{dia}$ quando os animais também receberam suplementação de $1,5 \mathrm{~kg}$ de milho. A suplementação da leucena com uma fonte energética propiciou melhores ganhos individuais.

\subsection{Suplementação energética}

Em situações em que a disponibilidade da forragem pastejada é muito baixa para alcançar as exigências energéticas dos animais, alguma forma de suplementação energética deve ser praticada para manter os níveis de produção desejados, e minimizar as perdas de peso. Isto geralmente ocorre 
durante os períodos de seca ou superpastejo com animais em crescimento e vacas leiteiras de alta produção (Canton \& Dhuyvetter, 1997).

As fontes de energia suplementar são extremamente variadas e incluem grãos, fontes de fibras rapidamente digestíveis (polpa cítrica e farelo proteinoso de milho (refinazil $\left.{ }^{\circledR}\right)$ ), fontes ricas em açúcar (melaço) e forragens de alta qualidade.

Quando o nível de suplemento energético oferecido aumenta, o consumo de forragem tende a diminuir. Segundo Garcés-Yépes et al.(1997), a utilização de concentrados energéticos em até $0.5 \%$ do peso vivo para bovinos, não altera o nível de ingestão e de digestibilidade da matéria seca ingerida. Em alguns casos, especialmente com ovinos, o consumo de forragem pode ser estimulado por baixos níveis de suplementação com grãos (Paterson et al., 1994; Canton \& Dhuyvetter, 1997). Baixos níveis de ingestão de grãos, possivelmente estimulem o crescimento microbiano, não diminuam a digestão da fibra $e$ aumentem o fluxo de proteína para o intestino delgado (Pordomingo et al.1991; Tjardes, et al. 1998).

Lake et al. (1974) observaram aumento na taxa de retenção de nitrogênio em novilhos de aproximadamente $280 \mathrm{~kg}$, pastejando forragens de alta qualidade (17-20\% de proteína bruta) com suplemento de $1,36 \mathrm{~kg}$ de milho/dia, em relação à animais não suplementados.

Segundo Reis et al. (1997) em pastagens com baixa disponibilidade de forragem, a suplementação energética obviamente resultará em maior resposta animal, pois nessas condiçōes os animais em pastejo não conseguem atingir o consumo máximo, e o suplemento energético terá pouco efeito adverso no consumo da forragem. Ao contrário, se a oferta é alta, ocorrerá resposta somente se a forragem for de baixo valor nutritivo, uma vez que há alto nível de substituição.

Essa redução no consumo de forragem associada à suplementação energética tem sido atribuída à modificação do ambiente ruminal, devido à abrupta queda no $\mathrm{pH}$ ruminal e diminuição da atividade das bactérias 
celulolíticas, o que resulta em decréscimo da digestão da fibra e diminuição do consumo de forragem (Parsons \& Allison, 1991; Canton \& Dhuyvetter, 1997; Pereira et al., 2001).

O efeito da suplementação energética sobre a digestibilidade pode ser dependente do nivel de proteína. Em situações em que a PB é limitante, somente suplementação energética teoricamente pode piorar as deficiências de PB e resultar em redução de consumo, digestibilidade e desempenho (Sanson et al., 1990).

Alterações no ambiente ruminal estão ligadas principalmente a rápida degradação do amido, e o aumento da concentração do ácido propiônico, levando a uma queda acentuada do $\mathrm{pH}$ ruminal.

A utilização de fontes energéticas com baixa concentração de amido e alta concentração de fibras de alta digestibilidade, como por exemplo a polpa citrica, pode ser uma alternativa para minimizar as alterações do ambiente ruminal e maximizar a utilização dos ingredientes da dieta.

Nas dietas com alto teor de polpa citrica, a uréia sanguínea foi significativamente menor que na dieta com milho. Partindo da informação que os teores de amônia no rúmen eram iguais, pode-se deduzir que houve maior retenção e, conseqüentemente, utilização mais eficiente da proteína pelos animais que receberam a polpa cítrica (Wing, 1982).

É provável que a introdução de polpa cítrica na dieta leve a um aumento na disponibilidade de energia para o animal a partir da fermentação ruminal (Rocha Filho et al. 1999).

Segundo Canton \& Dhuyvetter (1997), a maioria dos trabalhos avaliando características produtivas têm demonstrado melhorias resultantes da suplementação energética, independente da fonte de energia. Em bovinos em crescimento, o ganho de peso é freqüentemente melhorado pela suplementação energética.

Wagner et al. (1998) verificaram aumento na capacidade de suporte, ganho diário e produção de carne por área em função da suplementação 
alimentar com grãos. Entretanto a quantidade e qualidade da forragem disponivel para os bovinos, têm um importante efeito na resposta à suplementação com grãos.

O N.R.C. (1996) indica que com o incremento de grãos na dieta, a eficiência do uso da energia para ganho de peso aumenta.

Um ganho adicional de até $300 \mathrm{~g}$ por dia durante a estação de crescimento forrageiro, permitiria que os animais ganhassem até $50 \mathrm{~kg}$ a mais por ano, contribuindo significativamente para redução na idade de abate e na entrada das fêmeas em reprodução. Segundo Poppi \& Mclennan (1995), um aumento de $300 \mathrm{~g}$ no ganho de peso diário de animais de $200 \mathrm{~kg}$ no período de verão necessitaria de cerca de $150 \mathrm{~g}$ de proteína adicional chegando ao intestino. Essa proteína poderia ser oriunda de leguminosa, suplemento protéico ou ainda de um energético que melhorasse a síntese de proteína microbiana.

\subsection{Efeito de substituição}

O fornecimento de suplemento alimentar para bovinos em pastejo pode levar a diminuição da ingestão da forragem. Segundo Canto \& Dhuyvetter (1997) a redução no consumo de forragens por ruminantes em pastejo, devido à suplementação energética é denominada efeito de substituição.

Apesar de ser comum o efeito de substituição na suplementação de bovinos a pasto, o suplemento pode proporcionar aumento da ingestão de forragens de baixa qualidade, por proporcionar melhores condiçōes para degradação da fibra no rúmen. 
A redução na quantidade de forragem ingerida é expressa em proporção da quantidade do alimento suplementar consumido. O cálculo do efeito de substituição pode ser estimado usando a seguinte equação (Hodgson, 1990):

Eq. (1). $\quad E F=\frac{Q F I S S P L-Q F I C S P L}{Q S F} \times 100$

- $E F=$ efeito de substituição

- QFISSPL = quantidade de forragem ingerida sem suplementação.

- QFICSPL = quantidade de forragem ingerida com suplementação.

- $\mathrm{QSF}=$ quantidade de suplemento fornecido.

Se substituirmos os valores do numerador na equação, pelos valores de ingestão total (forragem + suplemento) e QFISSPL, respectivamente, teremos o valor do efeito de suplementação.

Outro fator que influi diretamente no efeito de substituição é a qualidade da forragem disponivel ao animal. Quanto melhor for a qualidade da forragem, maior será o efeito de substituição pelo suplemento (Reis et al. 1997).

Suplementos com alta concentração energética, e ricos em amido, reduzem mais acentuadamente o consumo de forragem, comparado a suplementos energéticos com maiores niveis de fibra, devido à queda do $\mathrm{pH}$ ruminal ocorrer de forma mais lenta com alimentos fibrosos (Kryls \& Hess, 1993).

\subsection{Refinazil ${ }^{\circledast}$ (corn gluten feed)}

A industrialização do milho dá origem a uma grande quantidade de subprodutos, de diversas características, que poderão ser utilizados para alimentação humana, animal, indústrias farmacêuticas, químicas, têxteis e de papel. Os subprodutos da industrialização são oriundos de moagem seca ou 
úmida do milho, sendo o refinazil ${ }^{\circledR}$ obtido somente através da moagem úmida do milho.

\subsubsection{Moagem úmida do milho:}

A moagem por via úmida é mais complexa que a moagem seca, onde a porção do amido é separada do resto do grão mecanicamente. Na via úmida, os principais componentes do grão, que são a proteína, o amido, a casca e o germe, são separados com maior eficiência.

Após a chegada do milho à indústria, ocorre limpeza, para retirada de palhas, terra, e outros materiais estranhos, através de separadores automáticos. Em seguida, os grãos são colocados em tanques denominados maceradores, imersos em água sulfatada com temperatura de aproximadamente $50^{\circ} \mathrm{C}$, em corrente contínua com $\mathrm{SO}_{2}$, transformando-se em $\mathrm{H}_{2} \mathrm{SO}_{3}$, responsável pela assepsia do processo e amolecimento dos grãos. A água resultante desse processo é chamada de água de maceração, sendo outro subproduto utilizado na alimentação animal. Os grãos após saírem dos tanques de maceração, com aproximadamente $50 \%$ de umidade, são moídos, separados o germe de onde será extraído o óleo comestível através de solventes, gerando outro subproduto denominado torta de germe ou germe desengordurado de milho ("corn germ meal"). A massa originada da separação do germe, contendo amido, glúten e casca, sofre uma segunda moagem, originando uma pasta, da qual através de centrifugação, são retirados o amido e o glúten.

Desse último processo, resultam as cascas que misturadas à água de maceração concentrada, e eventualmente com a torta de germe, dão origem ao farelo proteinoso de milho ("corn gluten feed"), que possui o nome comercial de refinazil $^{\circledR}$ (Corn Products Brasil) ou promi ${ }^{\otimes}$ (Cargill ${ }^{\otimes}$ ) (Figura 1). 
O refinazil ${ }^{\otimes}$ é composto basicamente pelas fibras digestíveis do grão do milho e resíduo do glúten, amido e frações protéicas não extraídas nos processos de industrialização. Por ser um produto comercial algumas especificações são garantidas pela empresa responsável, e estão descritas na Tabela 01.

O refinazil ${ }^{\circledast}$ possui um bom balanço de energia e proteína, boa palatabilidade e grande quantidade de fibra de alta digestibilidade, sendo assim um bom ingrediente para dietas de ruminantes. Por possuir grande quantidade de fibra digestivel, o refinazil ${ }^{\circledR}$ é uma boa alternativa para substituição do amido em dietas com altos níveis de concentrado, por amenizar a queda do $\mathrm{pH}$ ruminal. 


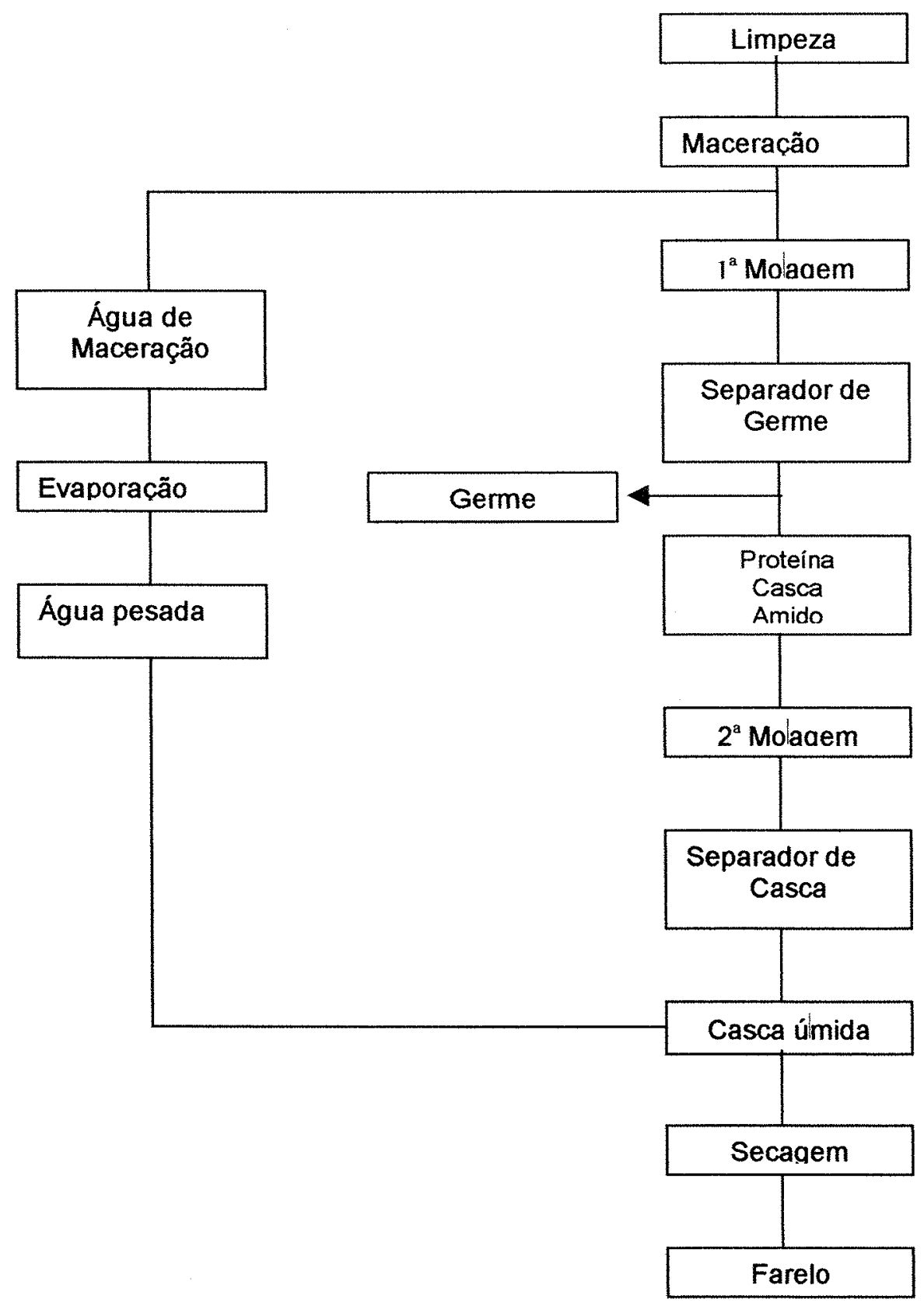

Figura 1- Esquema de obtenção de subprodutos do milho

Fonte: Pereira (1999) 
Tabela 1. Especificações físico-químicas garantidas do refinazil ${ }^{\circledR}$ seco.

\begin{tabular}{lcc}
\hline $\begin{array}{l}\text { NÍVEIS DE GARANTIA } \\
\text { (\%Matéria Orgânica) }\end{array}$ & MÍNIMO & MÁXIMO \\
\hline Umidade & - & 12,0 \\
Proteína & 21,0 & - \\
Extrato Etéreo & 1,0 & - \\
Matéria Fibrosa & - & 10,0 \\
Matéria Mineral & - & 8,0 \\
\hline
\end{tabular}

Fonte: Corn Products Brasil

O refinazil ${ }^{\circledR}$ úmido pode ser armazenado em silos "bunker", sem alterações das características físico-químicas, por pelo menos 43 dias. Podem ocorrer alterações na superfície do silo, porém o baixo $\mathrm{pH}$ do produto permite que o mesmo seja armazenado sem perda da qualidade DEMARCHI et al. (1998).

BOIN et al. (1985) não verificaram alteraçōes na $M S, p H, e$ características visuais durante 30 dias, em silos experimentais.

A utilização de subprodutos como o refinazil ${ }^{\circledR}$ e a polpa cítrica peletizada na suplementação de bovinos em pastejo, apresentam resultados satisfatórios, principalmente pelo fato desses ingredientes possuírem grande quantidade de fibra digestível, proporcionando grande quantidade de energia ao animal sem promover grandes quedas nos valores de pH no rúmen. Já a suplementação energética com amido, promove queda abrupta do $\mathrm{pH}$ ruminal, diminuindo os valores de digestibilidade da fibra. Baixos valores de $\mathrm{pH}$ atuam diretamente na digestibilidade da fibra devido à alta sensibilidade dos microorganismos celulolíticos, diminuição da atividade enzimática, menor fixação das bactérias às partículas do conteúdo ruminal e aumento nas taxas de passagem dos alimentos. 
O refinazil ${ }^{\circledast}$ pode ser utilizado em substituição parcial do milho, sem afetar o desempenho e a conversão alimentar, com diminuição dos custos de alimentação.

A substituição de 25 ou $50 \%$ da matéria seca de milho quebrado por refinazil ${ }^{\circledR}$ proporcionou melhora no ganho de peso e conversão alimentar de novilhos em confinamento (Richards, et al., 1998).

Peter et al., (2000) utilizando fêmeas cruzadas (Angus $x$ Simental) de aproximadamente $240 \mathrm{Kg}$ de peso vivo e dietas à base de milho e feno, observaram um aumento de $29 \%$ no ganho de peso e $34 \%$ na conversão alimentar com a suplementação na dieta de $2,5 \mathrm{Kg}$ de refinazil ${ }^{\circledR}$ seco.

Alleoni et al. (1990) trabalharam com animais confinados e silagem de sorgo, com concentrado à base de milho e farelo de algodão ou refinazil ${ }^{\circledR}$ úmido. A substituição foi feita equilibrando-se os teores de PB dos concentrados. Não foram observadas diferenças em relação ao ganho de peso diário e a conversão alimentar dos animais.

Segundo Possenti et al. (1998), as melhores degradabilidades da MS, FDN e PB da dieta, foram com os niveis de inclusão de $33 \%$ de fibra do grão de milho (refinazil ${ }^{\circledast}$ ) na MS da dieta, com dietas à base de feno de Coast cross.

\subsection{Polpa cítrica peletizada}

As indústrias brasileiras de suco de laranja geram uma grande quantidade de residuos, que podem causar grande contaminação ambiental. Vários estudos foram desenvolvidos no sentido da utilização desse resíduo na alimentação animal, substituindo fontes energéticas como o milho. A substituição parcial do milho por polpa cítrica proporciona queda nos custos de produção sem afetar o desempenho. 
Após a extração do suco, obtem-se um resíduo composto de casca, bagaço e sementes, que é peletizado para conservação e posterior utilização na nutrição animal.

Durante o processo de peletização, são alcançadas altas temperaturas, que podem possibilitar a ocorrência da reação de Maillard, indisponibilizando parte da proteína da polpa cítrica peletizada.

A polpa cítrica peletizada apresenta um teor de fibra maior que o milho e uma grande quantidade de pectina, que é um carboidrato estrutural de alta degradação ruminal. A grande quantidade de fibra degradável vai proporcionar grande quantidade de energia aos microorganismos ruminais, sem grandes alterações no $\mathrm{pH}$ ruminal.

Além disso, a polpa cítrica possui grandes quantidades de açúcar solúvel, sendo essa quantidade dependente da inclusão ou não de melaço após a peletização.

A concentração de ácidos graxos voláteis no rúmen teve aumento proporcional à entrada de polpa de citros na dieta, refletindo uma elevação na atividade microbiana devido à introdução de um alimento de rápida fermentação. Conseqüentemente, a polpa de citros estimulou a fermentação ruminal em comparação ao milho. Esta estimulação pode ter sido um efeito combinado das características fermentativas da pectina, da parede celular digestivel presente na polpa citrica e do alto teor de carboidratos solúveis existentes neste alimento (Carvalho, 1998).

\subsection{Efeitos da suplementação sobre parâmetros ruminais}

\subsection{1 Ácidos graxos voláteis (AGV'S)}

Os AGV'S presentes no rúmen são responsáveis por suprir $50-85 \%$ da energia metabolizável nos ruminantes. São constantemente produzidos e absorvidos, sendo a diferença entre a produção e absorção, a concentração 
presente no líquido ruminal (Owens \& Goetsch, 1988). Dentre os AGV'S, os de maior concentração ruminal são: o ácido acético, propiônico e butírico.

As proporções dos AGV'S vão depender do tipo de carboidrato fermentado, espécies de bactérias e ambiente ruminal. A produção dos AGV'S está intimamente ligada às características da dieta, sendo que o aumento da porcentagem de concentrado, vai levar tanto a aumento na produção total de AGV'S, como também a alterações nas concentrações dos mesmos.

Em dietas predominantemente volumosa as concentrações dos ácidos acético, propiônico e butírico são de aproximadamente 65:25:10, e nas dietas com altos niveis de concentrado, a proporção seria de 50:40:10. As mudanças no padrão de fermentação com dietas ricas em concentrado podem ser explicadas pela menor diversidade da microflora ruminal (Owens \& Goetsch, 1988).

$\mathrm{Na}$ fermentação ruminal de carboidratos estruturais, teremos principalmente a produção de ácido acético. Entretanto quando se aumentam as concentrações de carboidratos não estruturais e açucares solúveis, no caso dos alimentos concentrados, vai ocorrer uma maior produção de ácido propiônico.

Praticamente todo AGV produzido no rúmen é absorvido no próprio rúmen, no retículo e no omaso, sendo uma grande quantidade destes metabolizada no próprio tecido ruminal (Bergman, 1990).

\subsubsection{Nitrogênio amoniacal $\left(\mathrm{N}-\mathrm{NH}_{3}\right)$}

A amônia presente no líquido ruminal é oriunda da degradação de proteínas, peptídeos e aminoácidos. A presença de carboidratos juntamente com a amônia no líquido ruminal, vai permitir a síntese de proteína microbiana e proliferação dos microorganismos aí presentes. Os carboidratos irão fornecer energia na forma de ATP e o esqueleto carbônico para formação da proteína microbiana. 
A concentração do $\mathrm{N}-\mathrm{NH}_{3}$ é um balanço entre a produção e a utilização da amônia pelos microorganismos mais a absorção através do epitélio ruminal. Há uma enorme faixa de valores de $\mathrm{N}-\mathrm{NH}_{3}$, considerados ideais para a síntese de proteina microbiana no rúmen. Isso é devido, provavelmente a influência direta da dieta, e conseqüentemente do sistema produtivo ao qual está sendo submetido o animal, sobre a microflora e a concentração de $\mathrm{N}-\mathrm{NH}_{3}$ ruminal. $\mathrm{O}$ nível ideal de amônia no rúmen vai depender da quantidade de energia disponivel.

Baixa concentração de amônia ruminal diminui a eficiência de crescimento microbiano, porque o ATP é desviado do crescimento para o processo de captação de compostos nitrogenados através da glutamato sintetase (Owens \& Goetsch, 1988).

Segundo Hoover (1986), as concentrações mínimas de $\mathrm{N}-\mathrm{NH}_{3}$ no rúmen, necessárias para o crescimento microbiano e digestão da fibra são 3.3 e 8 $\mathrm{mg} / \mathrm{dl}$, respectivamente. Esses valores são próximos dos valores de Orskov (1988), que descreveu o valor $7 \mathrm{mg} / \mathrm{dl}$ como necessário para maximizar crescimento microbiano, porém muito distantes dos valores $15-20 \mathrm{mg} / \mathrm{dl}$ de Leng \& Nolan (1984).

A utilização da amônia ocorre de forma diferenciada entre os microorganismos ruminais, e são divididos de acordo com os carboidratos que fermentam. Os microorganismos que fermentam carboidratos estruturais crescem lentamente e utilizam somente amônia como fonte de nitrogênio para síntese de proteína. Por outro lado, os microorganismos que fermentam carboidratos não estruturais crescem mais rapidamente e utilizam aminoácidos, peptídeos e também amônia como fonte de nitrogênio para a síntese protéica (Russel et al. 1992).

A manutenção das quantidades de amônia no rúmen é de extrema importância, pois essa influi diretamente na produção de proteína microbiana, que é responsável pelo suprimento de aproximadamente $50 \%$ das exigências de proteína dos bovinos. 


\subsection{Efeitos da suplementação sobre parâmetros sanguíneos}

\subsubsection{Uréia sérica}

Os bovinos têm a capacidade de reciclagem de uréia, para ser utilizada pelos microorganismos ruminais como fonte de proteína. A reciclagem da uréia ocorre através da saliva e do sangue, sendo muito importante na manutenção do aporte constante de nitrogênio aos microorganismos ruminais.

A concentração de uréia sérica é fortemente influenciada pela extensão de degradação dos aminoácidos e pela quantidade de amônia absorvida pela parede ruminal. Portanto, a concentração de uréia presente no sangue, nos representa o balanço de nitrogênio da dieta, e conseqüentemente o suprimento das exigências de nitrogênio dos microorganismos ruminais e do animal.

Hennessy et al. (1995) e Rennó et al. (2000) observaram aumento linear da concentração de uréia sanguínea, em relação ao aumento da PB da dieta.

O aumento das concentrações sanguíneas de uréia é provavelmente resultado da maior absorção de amônia ruminal, oriunda de uma maior degradação protéica no rúmen (Hess et al., 1998).

Bandyk, et al. (2001) não observou diferença nas concentrações de uréia plasmática para suplementação protéica com fontes de diferentes locais de degradação (ruminal ou pós ruminal).

\subsection{Qualidade de carne}

Das características qualitativas da carne bovina, a maciez é a eleita pelos consumidores como a mais importante, porém a cor é um dos únicos, se não o único parâmetro avaliado pelo consumidor no momento da compra. Portanto, cor e maciez podem ser consideradas as características mais 
importantes da carne, e são diretamente influenciadas pela idade de abate do animal.

O sistema de terminação de bovinos, com o fornecimento de grãos ou não, vai ter efeito sobre a qualidade da carne oriunda desses animais (Luchiari Filho \& Pedreira, 2000).

Sistemas de terminação de bovinos em pastagens, não eram recomendados devido a menor quantidade de gordura de cobertura, gordura com coloração amarelada, escurecimento muscular, menor sabor e maciez, em relação aos animais terminados com dietas à base de grãos (Mandell, et al. 1997). Vários trabalhos não encontraram diferenças nos atributos de palatabilidade entre animais terminados a pasto ou confinados, porém deve-se considerar a grande variação qualitativa das forragens utilizadas em sistemas de pastejo.

Segundo Bowling et al., (1977), as carcaças de animais terminados exclusivamente em pastagens apresentam problemas quali-quantitativos, com maior porcentagem de carne magra, menor área de olho de lombo, menor quantidade de gordura subcutânea, carne escura e menos macia.

Os problemas citados acima podem ser minimizados, havendo melhora significativa na qualidade da carne de animais criados em pastagens se for realizado um período de terminação com o fornecimento de grãos (Keane \& Allen, 1998; Veestergaard et al. 2000).

Atualmente, há uma grande preocupação em relação à saúde humana, levando os consumidores a preferirem carne com menores proporçōes de gordura, gerando uma grande demanda por carcaças de animais produzidos a pasto. Porém, para se conseguir a produção de carne macia e com uma quantidade de gordura de cobertura adequada, faz-se necessário a utilização de tecnologias para aumentar a densidade energética da dieta no período de terminação. Técnicas como a suplementação a pasto podem ser utilizadas para se atingir esse objetivo. 
O principal problema em relação à carne de animais terminados a pasto seria em relação à maciez, devido à idade de abate desses animais. Vários fatores influem na maciez, como a idade, sexo, alimentação, grupo genético, manejo e outros. A utilização de suplementação alimentar de animais em pastejo durante os períodos de escassez forrageira propicia melhores ganhos diários, diminuindo-se a idade de abate desses animais.

\subsubsection{Espessura de gordura de cobertura}

A gordura de cobertura da carcaça é uma característica muito importante para se obter carne de boa qualidade, por atuar como um isolante térmico protegendo a carcaça durante o resfriamento, e influir significativamente no sabor. No resfriamento, a presença da gordura de cobertura vai impedir o escurecimento da superfície muscular e a ocorrência do "cold-shortening". O escurecimento da carcaça pode ocorrer durante o resfriamento, devido à desidratação da superfície muscular desprotegida. "Cold-shortening" é o fenômeno de encurtamento das fibras musculares, devido ao resfriamento intenso e rápido, levando a diminuição da maciez da carne quando da ausência de gordura de cobertura.

A medida de espessura de gordura de cobertura é feita na altura da $12^{\mathrm{a}}$ costela, sendo utilizada para avaliar o acabamento das carcaças. Pode ser feita por ultra-sonografia, mais utilizada em animais vivos, ou pela medida direta na carcaça. Não só a quantidade, mas também a distribuição da gordura de cobertura deve ser observada na avaliação de carcaças.

A quantidade de gordura de cobertura deve se situar entre $5-7 \mathrm{~mm}$, ou então 2-2,5 $\mathrm{mm}$ para $100 \mathrm{Kg}$ de carcaça. Deve-se lembrar que a quantidade mínima de gordura é variável, porém do ponto de vista qualitativo, um mínimo de 2-3 $\mathrm{mm}$ é sempre necessário. $O$ excesso de gordura na carcaça, além de indesejável, diminui o rendimento da porção comestivel e necessita ser aparado, implicando em desperdícios (Luchiari Filho, 2000). 


\subsection{2 Área de olho de lombo}

A área de olho de lombo é medida na altura da $12^{\mathrm{a}}$ costela, podendo ser feita através de ultra-sonografia ou medida direta na carcaça. Ë utilizada para avaliação da quantidade de músculos da carcaça, tendo correlação positiva com a quantidade da porção comestível e o rendimento de cortes.

As avaliações da musculosidade e do grau de acabamento são muito importantes na avaliação de carcaças, sendo as medidas de área de olho de lombo e de espessura de gordura na altura da $12^{\mathrm{a}}$ costela, internacionalmente aceitas como bons indicadores da musculosidade e da quantidade de gordura (Luchiari Filho, 2000). 


\section{MATERIAL E MÉTODOS}

\subsection{Local e duração}

O presente trabalho foi realizado na Estação Experimental Central do Instituto de Zootecnia, localizado no municipio de Nova Odessa, região leste do estado de São Paulo. O período experimental foi de 149 dias, tendo início no dia 26 do mês de junho de 2000 , e finalizado no dia 24 de novembro do mesmo ano com a avaliação da espessura de gordura das carcaças após resfriamento.

\section{2 Área experimental}

A área experimental é constituida por 48 piquetes de 1 hectare cada, com cochos cobertos para suplementação e bebedouros.

As parcelas experimentais foram representadas por uma área de 3,0 hectares, dividida em 3 piquetes de 1 hectare.

\subsection{Pastagem e manejo}

As áreas de pastagens utilizadas para pastejo dos animais experimentais são formadas de Brachiarria brizantha e bancos de proteina de Leucaena leucocephala, que foram estabelecidos em 1990, sendo feitas podas de manutenção quando necessário. Nos piquetes com banco de proteína, a leguminosa tinha representatividade de $25 \%$ da área do piquete, e os animais livre acesso ao banco de proteína dentro da parcela experimental. 
Anualmente é realizada adubação em cobertura de manutenção com $100 \mathrm{~kg} \mathrm{P} \mathrm{O}_{5} / \mathrm{ha}, 60 \mathrm{~kg} \mathrm{~K}$ O/ha e $100 \mathrm{~kg} \mathrm{~N} / \mathrm{ha}(500 \mathrm{~kg}$ de sulfato de amônio/ ha), no final do período das águas. Foi feita uniformização da disponibilidade de forragem aproximadamente 30 dias antes do início do período experimental.

Foi utilizado pastejo rotacionado dentro de cada parcela experimental, com períodos de descanso de aproximadamente 56 dias e ocupação em torno de 28 dias.

\subsection{Animais experimentais}

Para a avaliação do desempenho animal foram utilizados 128 bovinos machos castrados da raça Nelore, com idade e peso de aproximadamente 28 meses e $400 \mathrm{Kg}$, respectivamente. Foram utilizados 08 animais por parcela experimental.

Foram tomadas medidas preventivas de rotina para controle sanitário e vacinações de acordo com calendário estabelecido no centro de pesquisa onde foi realizado o experimento.

\subsection{Tratamentos}

Foi utilizado um delineamento experimental em blocos casualizados com quatro tratamentos e quatro repetiçōes, adicionado ao fator de medida de tempo. Sendo:

- Controle $=$ Pastagem de Brachiaria brizanta cv. marandu + suplemento mineral;

- Leucena = Pastagem de Brachiaria brizanta cv. marandu + Banco de proteina (Leucaena leucocephala) $+2 \mathrm{Kg}$ polpa cítrica peletizada $+2 \mathrm{Kg}$ refinazil úmido ${ }^{\circledR}$ (animal/dia) + suplemento mineral; 
- Supl.1 = Pastagem de Brachiaria brizanta $\mathrm{cv}$. marandu $+2 \mathrm{Kg}$ polpa cítrica peletizada $+2 \mathrm{Kg}$ refinazil úmido ${ }^{\circledR}+0.5 \mathrm{Kg}$ farelo de soja $+0.1 \mathrm{Kg}$ uréia (animal/dia) + suplemento mineral;

- Supl.2 = Pastagem de Brachiaria brizanta cv. marandu $+2 \mathrm{Kg}$ polpa cítrica peletizada $+2 \mathrm{Kg}$ refinazil ${ }^{\circledR}$ úmido $+1 \mathrm{Kg}$ farelo de soja $+0.1 \mathrm{Kg}$ uréia (animal/dia) + suplemento mineral.

\subsection{Suplementação Mineral e Alimentar}

\subsubsection{Suplemento Mineral}

A suplementação mineral foi fornecida "ad libitum" para todos os tratamentos, com observação constante de consumo para comparação e acerto entre os diferentes tratamentos, o que não foi necessário. $O$ suplemento mineral foi fornecido em cochos cobertos instalados em cada piquete.

O suplemento mineral utilizado durante o período experimental foi a formulação comercial $Q-85$ da marca Qualimix ${ }^{\circledR}$, com os seguintes niveis de garantia por $\mathrm{Kg}$ do produto: $\mathrm{P}(85,0 \mathrm{~g}), \mathrm{Ca}(130,0 \mathrm{~g}), \mathrm{Mg}(20 \mathrm{~g}), \mathrm{S}(30 \mathrm{~g})$, $\mathrm{Na}(120 \mathrm{~g}), \mathrm{Mn}(3000 \mathrm{mg}), \mathrm{Fe}(500 \mathrm{mg}), \mathrm{Zn}(4000 \mathrm{mg}), \mathrm{Cu}(1250 \mathrm{mg})$, Co (180 mg), I (120 mg), Se (25 mg).

\subsubsection{Suplemento alimentar}

O suplemento alimentar foi fornecido diariamente, em cochos cobertos instalados nos piquetes. Não foram observadas sobras do suplemento alimentar fornecido aos animais, sendo a ingestão dividida durante todo o dia, porém com maior intensidade pela manhă, logo após o fornecimento no cocho. 


\subsubsection{Caracterização do refinazil úmido ${ }^{\circledast}$ e polpa cítrica peletizada.}

O refinazil ${ }^{\circledR}$ é um subproduto que pode ser comercializado na forma seca ou úmida. No estado seco, apresenta como vantagem os custos de transporte e facilidade de armazenagem, porém com elevado custo de aquisição. Já a forma úmida ("Wet corn gluten feed"), apresenta as mesmas características físico-químicas da forma seca (Tabela 2), com aproximadamente $40 \%$ de MS e $22 \%$ de PB. Possui menores custos de aquisição, por não ter passado pelo processo de secagem, porém com desvantagens para transporte e armazenamento.

Tabela 2. Composição química do refinazil ${ }^{\circledR}$ úmido.

\begin{tabular}{lccccccccc}
\hline$\%$ MS & pH & MS & FDA & FDN & MM & LIG & EE & PB & NIDA \\
\hline Refinazil & 4,0 & 42,9 & 13,1 & 46,0 & 8,2 & 1,72 & 2,5 & 22,7 & 11,4 \\
Úmido & & & & & & & & &
\end{tabular}

Fonte: adaptado de DEMARCHI et al. (1998).

A conservação do refinazil ${ }^{\circledR}$ úmido durante o periodo experimental foi feita em silos "bunker", sem alterações nas características do produto.

\subsubsection{Polpa cítrica peletizada}

A polpa cítrica apresenta de 78 a $92 \%$ de digestibilidade da matéria seca e 40 a $65 \%$ de digestibilidade da PB. Caracterizando-se assim como um alimento com elevada digestibilidade, exceto no que se refere à PB (Carvalho, 1997).

Para formulação dos suplementos foi utilizada polpa cítrica peletizada adquirida em indústrias de extração de suco de laranja. (Tabela 3). 
Tabela 3. Composição química e conteúdo de energia bruta da polpa cítrica peletizada de origem brasileira.

\begin{tabular}{lc}
\hline $\begin{array}{l}\text { COMPONENTE } \\
\text { (\%matéria original) }\end{array}$ & POLPA CÍTRICA PELETIZADA \\
\hline Matéria Seca & 85,84 \\
Matéria Orgânica & 79,09 \\
Proteína Bruta & 6,64 \\
Extrato Etéreo & 2,54 \\
Fibra Bruta & 12,52 \\
Fibra em Detergente Neutro & 19,92 \\
Fibra em Detergente Ácido & 23,69 \\
Lignina & 1,12 \\
Celulose & 22,40 \\
NIDA & 11,24 \\
Cinzas & 6,75 \\
Cálcio & 1,99 \\
Fósforo & 0,18 \\
Energia Bruta (Kcal/Kg) & 3743
\end{tabular}

Fonte: Giraldo (1999)

\subsection{Pesagem dos Animais}

Foram realizadas pesagens de todos os animais em intervalos de aproximadamente 28 dias, tendo ocorrido nos dias: 26/06; 01/08; 29/08; $26 / 09 ; 31 / 10$ e 23/11/2000.

\subsection{Avaliação da forragem disponível}

A avaliação da disponibilidade de forragem (DISP) foi estimada pelo "Método do Quadrado", com quadrado de $1 \mathrm{~m}^{2}$ de tamanho. O corte da forragem disponível feito manualmente com auxilio de uma tesoura de jardinagem, a uma altura aproximada de 5 centímetros da superfície do solo. 
As avaliações de disponibilidade eram feitas antes da entrada dos animais em cada piquete.

As amostras da forragem (200 a 300 gramas de material fresco disponivel de cada piquete) foram submetidas a um processo de présecagem a $65^{\circ} \mathrm{C}$ por 72 horas em estufa com ventilação forçada.

Após secagem o material era moído, utilizando-se uma peneira de 1,0 $\mathrm{mm}$ de malha, para determinação da umidade residual através de secagem a $105{ }^{\circ} \mathrm{C}$, da proteína bruta (PB) pelo método micro Keejdahl (A.O.A.C. 1990), fibra em detergente neutro (FDN), fibra em detergente ácida (FDA) e lignina (LIG) Robertson \& Van Soest (1981).

\subsection{Coleta de amostras}

Foram realizadas coletas de líquido ruminal através de sonda flexivel oro-gástrica, segundo metodologia descrita Rosenberger (1987), para avaliação de amônia e ácidos graxos voláteis (AGV'S). Também foram feitas coletas de sangue, por venopunção da jugular em tubos de vidro, para avaliação dos níveis de uréia sanguínea.

As coletas foram realizadas de 19 a 22/09/2000 no período da manhã, antes do fornecimento do suplemento, sendo coletados os quatro tratamentos em todos os dias de manejo, correspondendo a um bloco experimental por dia. Foram coletadas amostras de 4 animais de cada parcela totalizando 16 animais por tratamento, escolhidos ao acaso por sorteio.

As amostragens de forragem para análise bromatológica foram feitas nos dias de avaliação das disponibilidades. Essas coletas foram feitas nos dias: $19 / 07 ; 21 / 08 ; 19 / 09$ e 16/10/2000. 


\subsection{Determinações no líquido ruminal}

\section{$3.10 .1 \mathrm{pH}$}

Medidas de $\mathrm{pH}$ foram realizadas imediatamente após as coletas do líquido ruminal, utilizando-se de um potenciômetro digital portátil, modelo PS-30 da marca Corning ${ }^{\circledR}$.

\subsection{2 Ácidos graxos voláteis}

As amostras de líquido ruminal para determinação de ácidos graxos voláteis (acético, propiônico, e butírico) foram centrifugadas a $15000 \mathrm{~g} \mathrm{a} 4{ }^{\circ} \mathrm{C}$ por 60 minutos. Os ácidos graxos voláteis foram determinados por cromatografia gasosa, segundo método preconizado por Palmiquist \& Conrad (1971), em cromatógrafo líquido-gasoso (Hewlett Packard 5890 Series II GC), equipado com integrador (Hewlett Packard 3396 Series II Integrator) e injetor automático (Hewlett Packard 6890 Series Injector). Foi utilizado como padrão interno o ácido2-metilbutírico, acrescentando-se 100 $\mathrm{l}$ do padrão, $800 \mu l$ da amostra e $200 \mu l$ de ácido metafosfórico, em cada tubo para leitura. Uma mistura de ácidos graxos voláteis (Allech ${ }^{\circledR}$ ) com concentração conhecida foi utilizada como padrão externo para a calibração do integrador.

\subsubsection{Amônia}

$\mathrm{Na}$ preparação das amostras para determinação das concentrações de amônia no líquido ruminal, foram colocados $2 \mathrm{ml}$ de fluido ruminal em tubos de ensaios contendo $1 \mathrm{ml}$ de ácido sulfúrico $1 \mathrm{~N} \mathrm{e}$ armazenados sob refrigeração até a realização das análises. As determinações de amônia foram feitas segundo método proposto por Chaney \& Marbach (1962), adaptado para leitura em leitor de microplaca (BIO-RAD, Hercules, CA, EUA) 
utilizando-se filtro para absorbância de $550 \mathrm{~nm}$. As soluções padrões utilizadas foram de $0 ; 1 ; 2 ; 4 ; 8 ; 16$; e $32 \mathrm{mg} / \mathrm{dL}$ de amônia. Foram utilizadas alíquotas de $40 \mu \mathrm{l}$ de amostra ou padrão incubados em banho-maria a $37^{\circ} \mathrm{C}$ por 10 minutos, juntamente com $2,5 \mathrm{ml}$ de reagente fenol e $2,0 \mathrm{ml}$ de reagente hipoclorito. As amostras foram submetidas ao leitor de microplacas. Somente foram aceitos resultados provenientes de placas com $r^{2}=0,99$ e coeficiente de variação entre duplicatas $\leq 5 \%$.

Tanto as avaliações de amônia ruminal como de ácidos graxos voláteis foram realizadas no laboratório de análises quimicas do Departamento de Nutrição e Produção Animal da Escola Superior de Agricultura "Luiz de Queiroz"/USP.

\subsection{Determinações sanguineas}

Após a retirada de sangue, os tubos permaneceram em temperatura ambiente para retração do coágulo e posteriormente centrifugados a 3.000 rpm durante 15 minutos. Uma alíquota do sobrenadante foi armazenada à $20^{\circ} \mathrm{C}$ até o momento da análise, feita em duplicata.

As determinações dos niveis séricos de uréia foram realizadas no laboratório de análises químicas do Departamento de Nutrição e Produção Animal da Escola Superior de Agricultura "Luiz de Queiroz"/USP, segundo método descrito por Chaney e Marbach (1962), adaptado para leitura leitor de microplaca (BIO-RAD, Hercules, CA, EUA) utilizando-se filtro para absorbância de $550 \mathrm{~nm}$. Utilizou-se a enzima urease (U-1500, Sigma), e soluções padröes com concentração de $0 ; 3,75 ; 7,5 ; 15$; e $30 \mathrm{mg} / \mathrm{dL}$ de Nureico. Somente foram aceitos resultados provenientes de placas com $r^{2}=$ 0,99 e coeficiente de variação entre duplicatas $\leq 5 \%$. 


\subsection{Determinação da espessura de gordura de cobertura (EG)}

Determinações de espessura de gordura de cobertura foram realizadas em todos animais na altura da $12^{\mathrm{a}}$ costela. As medidas foram feitas através de ultra-sonografia, no dia anterior ao abate. Foi utilizado óleo vegetal como acoplante acústico e aparelho de ultra-som da marca Piemedical Scanner 200 VET, com transdutor linear de $3,5 \mathrm{MHZ}$ e $18 \mathrm{~cm}$ com guia acústica.

Foram feitas também medidas diretas na carcaça dos animais abatidos, realizadas na indústria frigorífica, após 15 horas de resfriamento. Não foi possível fazer as avaliações com $24 \mathrm{~h}$ de resfriamento, por não ser possivel a manipulação das carcaças dentro da planta nesse horário.

\subsection{Determinação da área de olho de lombo (AOL)}

As determinações de AOL foram feitas somente através de ultrasonografia, no mesmo dia das avaliações de espessura de gordura de cobertura.

\subsection{Análise Estatística}

Os resultados foram analisados através do programa computacional Statistical Analysis System (SAS Institute Inc, 1985), sendo anteriormente verificada a normalidade dos resíduos pelo Teste de Shaphiro-wilk (PROC UNIVARIATE) e as variâncias comparadas pelo Teste F. Os dados que não atenderem a estas premissas foram submetidos à transformação logarítima $[\log (X+1)]$ ou pela raiz quadrada $[R Q(X+1 / 2)]$.

Os dados originais ou transformados, quando este último procedimento foi necessário, eram submetidos a analise de variância pelo procedimento GLM (PROC GLM). Foi adotado o nível de significância de $5 \%$ para todos os testes realizados. Essa análise foi realizada utilizando-se o 
comando REPEATED gerado pelo procedimento GLM (PROC GLM do SAS), segundo esquema de variância apresentado na Tabela 5.

Tabela 4. Esquema de análise de variância

\begin{tabular}{ll}
\hline Fontes de Variação & Graus de Liberdade \\
\hline Tratamento & 3 \\
Bloco & 3 \\
Bloco X Tratamento & 9 \\
Resíduo A (animal (bloco*trata)) & 112 \\
Sub - Total & 127 \\
Efeito de Tempo & 5 \\
Interação tempo X tratamento & 15 \\
Resíduo B & 615 \\
Total & 762 \\
\hline
\end{tabular}




\section{RESULTADOS E DISCUSSÃO}

\subsection{Disponibilidade e qualidade da forragem}

As disponibilidades de forragem não apresentaram diferença estatística $(P \leq 0,05)$ entre os tratamentos durante o período experimental (Tabela 1 e Figura 2).

Houve efeito de tempo na disponibilidade de forragem, com maiores disponibilidades no mês de julho e outubro, apresentando uma distribuição quadrática dentro do período experimental. Entretanto, foi observado um aumento, não significativo estatisticamente, na quantidade de forragem disponível para o tratamento controle, quando os animais voltaram ao primeiro piquete de pastejo (aproximadamente 90 dias de experimento). Isso provavelmente ocorreu devido uma maior quantidade de residuo proveniente do pastejo anterior em relação aos tratamentos suplementados, nos dando indícios de aumento na ingestão de forragem devido à suplementação protéica (Figura 2).

O aumento na ingestão de forragens de baixa qualidade, em reposta a suplementação protéica foi demonstrada por vários autores. (Koster et al., (1996); Mathis et al., (1999); Bodine et al., (2000); Riordan, et al., (2001); Elgersma, et al., (2001)). 


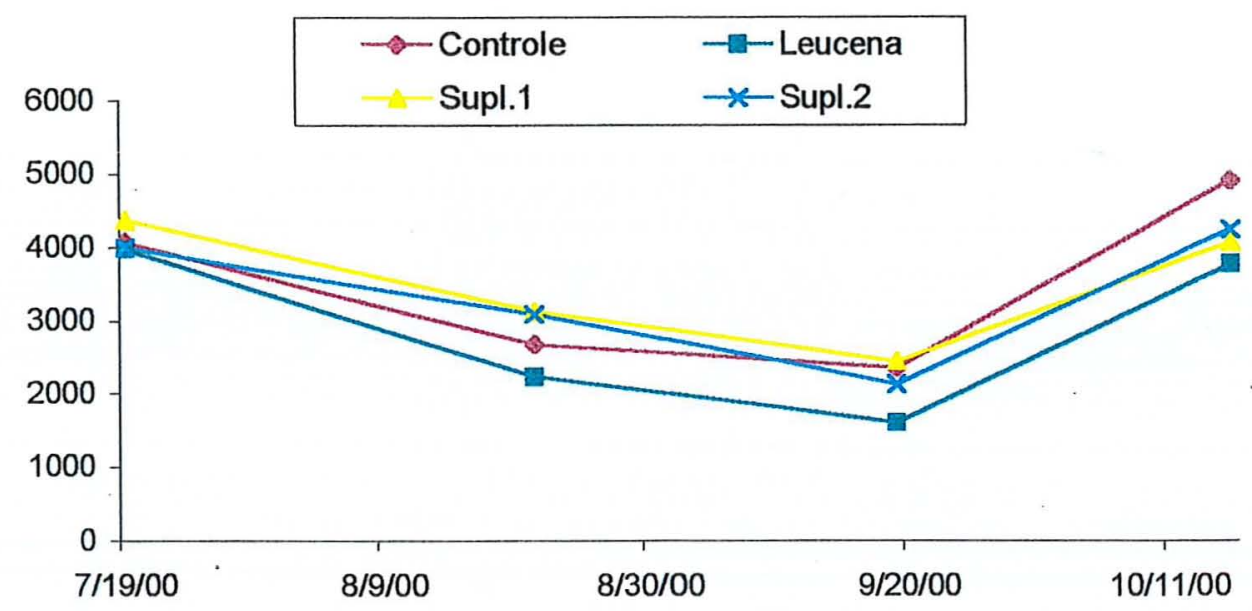

Figura 2 - Disponibilidades médias de forragem dentro dos diferentes tratamentos durante todo o período experimental.

A variação de desempenho do grupo controle acompanhou as mudanças da disponibilidade de forragem, porém o teor de proteína na pastagem parece ter sido o fator limitante para a retomada de ganho de peso desse tratamento. Isso ocorreu quando os teores de PB da pastagem atingiram o nivel de $4,9 \%$.

Os teores de PB da forragem apresentaram aumento linear no decorrer do período experimental, proporcionando aos animais, maior quantidade com baixa qualidade no primeiro período, e alta disponibilidade e boa qualidade no último período experimental devido ao início das chuvas no mês anterior (Tabela 5). 
Tabela 5. Disponibilidade, matéria seca, proteína bruta, fibra em detergente ácido, fibra em detergente neutro e lignina da forragem nos diferentes tratamentos durante o periodo experimental.

\begin{tabular}{|c|c|c|c|c|c|c|c|}
\hline DATA & Tratamentos & $\begin{array}{l}\text { DISP } \\
(\mathrm{Kg})\end{array}$ & $\%$ MS & $\begin{array}{l}\text { PB } \\
(\% M S)\end{array}$ & $\begin{array}{l}\text { FDA } \\
\text { (\%MS) }\end{array}$ & $\begin{array}{l}\text { FDN } \\
(\% M S)\end{array}$ & $\begin{array}{l}\text { LIG } \\
\text { (\%MS) }\end{array}$ \\
\hline \multirow[t]{5}{*}{$19 / 07 / 2000$} & Controle & 4067 & 51,78 & 2,60 & 45,41 & 77,61 & 4,60 \\
\hline & Leucena & 3975 & 51,27 & 2,70 & 45,72 & 75,61 & 4,42 \\
\hline & Supl.1 & 4375 & 52,02 & 2,45 & 45,35 & 77,85 & 4,34 \\
\hline & Supl.2 & 4000 & 52,06 & 2,58 & 44,86 & 75,20 & 4,59 \\
\hline & MÉDIA & 4104 & 51,78 & 2,58 & 45,33 & 76,57 & 4,49 \\
\hline \multirow[t]{5}{*}{$21 / 08 / 2000$} & Controle & 2667 & 58,67 & 3,17 & 48,16 & 78,21 & 6,48 \\
\hline & Leucena & 2225 & 57,17 & 3,02 & 50,97 & 79,60 & 6,75 \\
\hline & Supl.1 & 3125 & 58,45 & 3,47 & 48,21 & 78,77 & 6,38 \\
\hline & Supl.2 & 3086 & 56,49 & 3,18 & 49,58 & 78,62 & 6,62 \\
\hline & MÉDIA & 2776 & 57,69 & 3,21 & 49,23 & 78,80 & 6,56 \\
\hline \multirow[t]{5}{*}{$19 / 09 / 2000$} & Controle & 2350 & 43,51 & 4,59 & 46,74 & 74,29 & 6,53 \\
\hline & Leucena & 1600 & 47,74 & 4,28 & 47,75 & 75,23 & 6,71 \\
\hline & Supl.1 & 2450 & 41,93 & 4,97 & 47,10 & 73,96 & 6,63 \\
\hline & Supl.2 & 2129 & 43,51 & 5,65 & 44,61 & 72,60 & 6,01 \\
\hline & MÉDIA & 2132 & 44,17 & 4,87 & 46,55 & 74,02 & 6,47 \\
\hline \multirow[t]{5}{*}{$16 / 10 / 2000$} & Controle & 4917 & 34,31 & 5,72 & 42,91 & 71,95 & 5,40 \\
\hline & Leucena & 3775 & 33,74 & 6,14 & 41,35 & 71,85 & 5,22 \\
\hline & Supl.1 & 4075 & 37,26 & 7,81 & 38,58 & 70,15 & 4,73 \\
\hline & Supl.2 & 4243 & 34,19 & 6,75 & 40,92 & 71,33 & 5,05 \\
\hline & MÉDIA & 4252 & 34,87 & 6,60 & 40,94 & 71,32 & 5,10 \\
\hline \multicolumn{8}{|c|}{ MÉDIA GERAL DE TODO PERIOODO EXPERIMENTAL } \\
\hline & Controle & 3807 & 47,06 & 3,30 & 45,56 & 75,91 & 5,10 \\
\hline & Leucena & 3340 & 48,36 & 3,37 & 46,19 & 76,26 & 5,37 \\
\hline & Supl.1 & 3378 & 47,41 & 3,76 & 46,07 & 76,29 & 5,55 \\
\hline & Supl.2 & 3197 & 46,56 & 3,80 & 46,58 & 76,36 & 5,80 \\
\hline
\end{tabular}


Não foram avaliadas as disponibilidades de leucena durante o periodo experimental, sendo observado um desenvolvimento semelhante ao da forrageira, com maiores disponibilidades no primeiro e no último período experimental. Avaliações feitas na mesma área em experimento anterior, mostraram os seguintes valores para PB e digestibilidade (Tabela 6). Esses valores correspondem à composição dos folíolos que foram separados das hastes para análises laboratoriais.

Tabela 6. Proteína bruta e digestibilidade "in vitro" da leguminosa (Leucaena leucocephala).

\begin{tabular}{lccccc}
\hline$\%$ MS & Julho/99 & Agosto/99 & Setembro/99 & Outubro/99 & Novembro/99 \\
\hline PB & 27,6 & 24,8 & 29,3 & 26,8 & 24,6 \\
DIVMS* & 48,9 & 59,9 & 60,9 & 65,7 & 56,4
\end{tabular}

Fonte: Lourenço et al. (2001)

"Digesibilidade "in vitro" da matéria seca

Os dados de temperatura e quantidade de chuva mostram ter ocorrido um inverno com temperaturas baixas, porém com boas quantidades de chuva (Tabela 7). Além da estacionalidade de crescimento e da alta taxa de senescência da forragem, o aspecto meteorológico pode ter sido mais um fator atuando para a queda da disponibilidade no segundo e terceiro períodos (agosto e setembro), promovendo deterioração da massa de forragem acumulada. 
Tabela 7. Dados meteorológicos mensais coletados no Instituto de Zootecnia - Nova Odessa/SP durante o ano de 2000.

\begin{tabular}{lccc}
\hline & $\begin{array}{c}\text { Temperatura } \\
\text { máxima }\left({ }^{\circ} \mathrm{C}\right)\end{array}$ & $\begin{array}{c}\text { Temperatura } \\
\text { mínima }\left({ }^{\circ} \mathrm{C}\right)\end{array}$ & Chuvas $(\mathrm{mm})$ \\
\hline Janeiro & 30,69 & 16,69 & 184,2 \\
Fevereiro & 30,93 & 18,54 & 148,8 \\
Março & 31,18 & 17,86 & 199,8 \\
Abril & 30,91 & 13,67 & 0 \\
Maio & 27,84 & 10,48 & 4,0 \\
Junho & 28,41 & 10,20 & 8,6 \\
Julho & 25,74 & 7,9 & 68,80 \\
Agosto & 27,51 & 11,19 & 67,80 \\
Setembro & 28,57 & 14,53 & 87,80 \\
Outubro & 33,51 & 16,88 & 96,2 \\
Novembro & 31,63 & 17,04 & 202,8 \\
Dezembro & 30,21 & 18,09 & 268,4
\end{tabular}

Fonte: Estaçāo meteorológica do Instituto de Zootecnia - Nova Odessa

\subsection{Composição dos suplementos fornecidos}

Os suplementos foram compostos a partir de 3 subprodutos agroindustriais e uréia. O suplemento alimentar do tratamento leucena continha somente polpa cítrica e refinazil ${ }^{\circledR}$, proporcionando uma suplementação energética aos animais deste grupo. Já os tratamentos Supl.1 e 2 apresentavam farelo de soja e uréia, além de refinazil ${ }^{\circledR}$ e polpa cítrica, promovendo dois níveis de proteína suplementar nesses tratamentos (Tabela 8). 
Tabela 8. Composição bromatológica dos suplementos alimentares fornecidos nos diferentes tratamentos

\begin{tabular}{lccccccccc}
\hline Tratamentos & $\%$ MS & PB & FB & EE & MM & FDN & FDA & ENN \\
\cline { 2 - 8 } & \multicolumn{6}{c}{ Valores em \% MS } \\
\hline Leucena & 64,26 & 12,17 & 15,52 & 2,34 & 7,12 & 34,17 & 30,62 & 62,85 \\
Supl.1 & 65,74 & 27,06 & 14,09 & 2,17 & 6,94 & 30,98 & 26,42 & 49,74 \\
Supl.2 & 67,03 & 27,50 & 13,91 & 1,96 & 6,84 & 30,53 & 25,76 & 49,84 \\
\hline
\end{tabular}

$\mathrm{FB}=$ fibra bruta

$E E=$ extrato etéreo

$\mathrm{MM}=$ matéria mineral

$\mathrm{ENN}=$ extrativo não nitrogenado

\subsection{Parâmetros ruminais:}

\subsection{1 Ácidos Graxos Voláteis}

As concentrações dos ácidos acéticos, propiônico e butírico não foram estatisticamente $(P \leq 0,05)$ diferentes nos diferentes tratamentos (Tabela 9). Com o fornecimento de alimentos concentrados esperava-se um aumento na produção de ácido propiônico no líquido ruminal dos animais suplementados em relação ao controle, por ser esse o principal produto da fermentação de carboidratos não estruturais. A falta de detecção nos aumentos de ácido propiônico pode ter ocorrido devido o horário de coleta do líquido ruminal (pela manhã antes do fornecimento do suplemento).

Resultados semelhantes ao encontrado no nosso trabalho foram observados por Pordomingo et al., (1991); Freeman et al., (1992); Elizalde et al. (1998); Driedger \& Loerch, (1999); Peter et al. (2000). 
Tabela 9. Concentração dos AGV'S nos diferentes tratamentos

\begin{tabular}{lllll}
\hline Tratamentos & \multicolumn{4}{c}{ AGV'S (mMol/ml) } \\
\cline { 2 - 5 } & Acético & Propiônico & Butírico & Ace:Prop \\
\hline \multirow{2}{*}{ Controle } & $79,31^{\mathrm{a}} \pm 5,17$ & $18,15^{\mathrm{a}} \pm 1,38$ & $10,50^{\mathrm{a}} \pm 0,83$ & $4,44^{\mathrm{a}} \pm 0,13$ \\
Leucena & $87,12^{\mathrm{a}} \pm 8,42$ & $20,35^{\mathrm{a}} \pm 2,09$ & $13,70^{\mathrm{a}} \pm 1,34$ & $4,34^{\mathrm{a}} \pm 0,14$ \\
Supl.1 & $84,57^{\mathrm{a}} \pm 8,26$ & $20,68^{\mathrm{a}} \pm 2,80$ & $11,91^{\mathrm{a}} \pm 1,64$ & $4,32^{\mathrm{a}} \pm 0,16$ \\
Supl.2 & $80,15^{\mathrm{a}} \pm 9,51$ & $18,33^{\mathrm{a}} \pm 2,24$ & $12,39^{\mathrm{a}} \pm 0,69$ & $4,49^{\mathrm{a}} \pm 0,15$ \\
\hline \multicolumn{4}{c}{ *Valores seguidos de letras diferentes diferem estatisticamente $(P \leq 0,05)$}
\end{tabular}

\subsection{2 $\mathrm{pH}$ ruminal}

Não foram observadas diferenças significativas para os valores de $\mathrm{pH}$ entre os tratamentos (Tabela 10), estando de acordo com outros trabalhos encontrados na literatura (Pordomingo, et al. 1991; Villela et al., 1997; Elyzalde et al., 1998; Queiroz et al., 1998; Bandyk, 2001).

Os valores encontrados no nosso experimento foram aproximadamente uma unidade maior que os valores citados na literatura para dietas semelhantes. Essa diferença estaria relacionada ao método e o momento de coleta do líquido ruminal (Lavezzo, 1986; Oliveira et al., 1999). A coleta através de sonda oro-esofágica apresenta contaminação por saliva, promovendo elevação do pH da amostra coletada (Lavezzo, 1986).

Tabela 10. Valores de $\mathrm{pH}$ ruminal para os diferentes tratamentos

\begin{tabular}{lc}
\hline Tratamentos & pH líquido ruminal \\
\hline Controle & $7,33^{\mathrm{a}} \pm 0,12$ \\
Leucena & $7,35^{\mathrm{a}} \pm 0,12$ \\
Supl.1 & $7,30^{\mathrm{a}} \pm 0,17$ \\
Supl.2 & $7,29^{\mathrm{a}} \pm 0,12$ \\
\hline \multicolumn{2}{c}{ *Valores seguidos de letras diferentes diferem estatisticamente $(\mathrm{P} \leq 0,05)$}
\end{tabular}




\subsubsection{Concentrações de amônia ruminal}

As concentrações de amônia no líquido ruminal (Tabela 11) dos animais dos grupos Supl.1 e 2 atingiram valores considerados mínimos, segundo Hoover (1986) de $8 \mathrm{mg} / \mathrm{dl}$, para crescimento microbiano e digestão da fibra. Já os animais controle apresentaram valores mínimos necessários para o crescimento microbiano $(3,3 \mathrm{mg} / \mathrm{d})$, porém abaixo do valor para máxima digestão de fibra que é de $8 \mathrm{mg} / \mathrm{dl}$ (Hoover, 1986).

Tabela 11. Concentração de amônia no líquido ruminal dos diferentes tratamentos

\begin{tabular}{lc}
\hline Tratamentos & $\begin{array}{c}\text { Concentração de amônia } \\
(\mathrm{mg} / \mathrm{dl})\end{array}$ \\
\hline Controle & $4,96^{\mathrm{a}} \pm 0,38$ \\
Leucena & $6,17^{\mathrm{ab}} \pm 0,46$ \\
Supl.1 & $7,70^{\mathrm{bc}} \pm 0,72$ \\
Supl.2 & $9,69^{\mathrm{c}} \pm 1,05$ \\
\hline
\end{tabular}

A amônia absorvida pelo epitélio ruminal é levada ao fígado através do sistema porta, onde é transformada em uréia, principal forma de eliminação da proteína em mamíferos. A concentração de amônia ruminal está diretamente relacionada aos teores de proteína da dieta, sendo ambas relacionadas às concentrações de uréia plasmática (Moss \& Murray, 1992).

A disponibilização adequada de energia no rúmen através da polpa citrica e do refinazil ${ }^{\circledR}$, permitiu uma boa utilização da amônia pelos microorganismos ruminais para sintese de proteina microbiana, melhorando a digestibilidade da fibra dos alimentos e $o$ aporte de proteína microbiana ao intestino. Porém, o acúmulo de amônia no rúmen pode ser devido à deficiência de energia suficiente para utilização das maiores quantidades de amônia disponiveis, ou a disponibilização acima do que os microorganismos seriam capazes de absorver. 
O aumento das concentrações de amônia devido a maiores teores de PB na dieta também foi demonstrado Koster et al., (1996); Valadares et al., (1997); Shain et al., (1998) Queiroz, et al. (1998); Mathis et al., (1999); Olson et al., (1999); Bodine, et al., (2000); Bandyk, et al., (2001).

\subsection{Parâmetros sanguíneos}

\subsubsection{Uréia sérica}

Segundo Hammond (1994) as concentrações médias de uréia sanguinea de um rebanho pode ser utilizada para avaliação do "status" protéico da dieta, devendo estar entre 9 e $12 \mathrm{mg} / \mathrm{dl}$. Se as concentrações forem acima de $12 \mathrm{mg} / \mathrm{dl}$, provavelmente há excesso de proteína, e se os valores estiverem abaixo de $9 \mathrm{mg} / \mathrm{dl}$, poderia-se aumentar a produção desses animais com aumento do teor de proteína da dieta.

No presente trabalho, os níveis de uréia sanguínea aumentaram de acordo com o aumento dos teores de proteína do suplemento. As concentrações de uréia sanguínea dos animais do tratamento Supl.2 foram significativamente maiores $(P \leq 0,05)$ que os demais tratamentos. Não houve diferença estatística $(P \leq 0,05)$ entre os tratamentos controle, leucena $e$ Supl.1 (Tabela 12). Isso indica possivelmente que o tratamento Supl.2 proporcionou uma concentração de amônia ruminal maior do que as quantidade absorvidas pelos microorganismos, sendo esse excesso transformado em uréia e eliminado.

Os aumentos dos niveis de uréia sanguíneos em relação aos aumentos da quantidade de PB da dieta, estão de acordo com os trabalhos de Moss \&Murray (1992); Hess, et al., (1998); Rennó et al. (2000).

No período de coleta do líquido ruminal (setembro), o teor de proteína da pastagem foi de $4,9 \%$ PB. Com o aumento da PB da pastagem para $6,6 \%$ nos últimos dois períodos, provavelmente o Supl.2 atingiu níveis acima de 12 $\mathrm{mg} / \mathrm{dl}$, que segundo Hammond (1994) há uma demanda de energia para excreção do excesso protéico. 
Tabela 12. Concentrações sanguíneas de uréia nos diferentes tratamentos

\begin{tabular}{lc}
\hline Tratamentos & $\begin{array}{c}\text { Uréia sérica } \\
\text { (mg/dl) }\end{array}$ \\
\hline & \\
Controle & $5,25^{\mathrm{a}} \pm 0,35$ \\
Leucena & $5,43^{\mathrm{a}} \pm 0,56$ \\
Supl.1 & $7,46^{\mathrm{a}} \pm 0,88$ \\
Supl.2 & $10,56^{\mathrm{b}} \pm 0,89$ \\
\hline *Valores seguidos de letras diferentes diferem estatisticamente $(\mathrm{P} \leq 0,05)$
\end{tabular}

A alta correlação existente entre a proteína ingerida, e as concentrações de amônia ruminal e uréia plasmática, permitem a utilização desses parâmetros para avaliação do nível protéico da dieta.

\subsection{Desempenho animal}

Avaliando-se o periodo total (149 dias), os animais dos tratamentos Supl. 1 e 2 apresentaram maiores ganhos médios diários $(G M D)(P \leq 0,05)$ em relação aos animais dos grupos controle e leucena, sendo o GMD do leucena significativamente maior que o controle (Tabela 13).

Os maiores GMD encontrados para os animais suplementados estão de acordo com outros trabalhos descritos na literatura. (Hennessy et al., 1983; Karges et al., 1992; Elyzalde et al. 1998; Paziani, et al., 1998; Ramos et al., 1998; Ruas, et al., 2000; Bandyk et al., 2001).

O desempenho observado para o tratamento leucena mais suplementação energética, propiciou ganhos de $0,528 \mathrm{Kg} / \mathrm{cab} /$ dia. Esse valor é superior aos ganhos de $0,277 \mathrm{Kg} / \mathrm{cab} / \mathrm{dia}$ observados por Manella (2000) durante a seca, em trabalho realizado na mesma área experimental sem utilização de suplementação energética. 
Tabela 13. Ganhos médios diários durante todo periodo experimental para os diferentes tratamentos.

\begin{tabular}{ll}
\hline Tratamentos & GMD (Kg/dia) \\
\hline Controle & $0,114^{\mathrm{a}} \pm 0,051$ \\
Leucena & $0,528^{\mathrm{b}} \pm 0,042$ \\
Supl. 1 & $0,638^{\mathrm{c}} \pm 0,035$ \\
Supl.2 & $0,613^{\mathrm{c}} \pm 0,031$ \\
\hline
\end{tabular}

*Valores seguidos de letras diferentes diferem estatisticamente $(P \leq 0,05)$

Não houve diferença significativa $(P \leq 0,05)$ no desempenho dos animais dos tratamentos Supl.1 e 2, sendo que o acréscimo de $0,5 \mathrm{Kg}$ de farelo de soja/animal/dia não proporcionou melhores ganhos aos animais do tratamento Supl.2. Esse fato mostra que provavelmente a relação proteína:energia da dieta ingerida no tratamento Supl.2 atingiu niveis acima do recomendado, levando a um aumento excessivo das concentrações de amônia no líquido ruminal. A provável maior quantidade de proteína na dieta do tratamento Supl.2, pode ter levado a desvio da energia disponivel para ganho na eliminação do excesso protéico. Esse custo em energia ocorre na transformação de amônia em uréia, no ciclo da uréia, e é conhecido como custo uréia.

Os animais do tratamento Supl.1 provavelmente conseguiram suprir suas exigèncias de proteina, igualando o GMD entre os animais dos tratamentos Supl. 1 e 2.

A suplementação alimentar proporcionou uma maior velocidade de crescimento aos animais suplementados em relação ao grupo controle. Entretanto, houve interação tempo $x$ tratamento, sendo diferentes os GMD nos diferentes períodos experimentais (Tabela 14), devido às variaçōes na quantidade e qualidade de forragem durante o período experimental. As variações dos GMD dentro dos tratamentos suplementados entre os diferentes períodos (Tabela 14), provavelmente foram devido à variação no valor nutritivo da dieta total. 
No primeiro periodo, observou-se maiores ganhos $(P \leq 0,05)$ para os tratamentos Supl.1 e 2 em relação ao leucena e controle. No segundo e terceiro períodos as diferenças em desempenho foram estatisticamente superiores $(P \leq 0,05)$ para os tratamentos leucena, Supl.1 e 2, em relação ao grupo controle, sem haver diferença estatística entre os suplementos. Não houve diferença entre os quatro tratamentos no quarto período experimental (outubro), provavelmente devido ao início das chuvas e aumento da quantidade e qualidade da forragem disponível. Esses fatos devem ter proporcionado aos animais do tratamento controle melhores condições nutricionais, satisfazendo as exigências de PDR, com isso melhorando a digestibilidade da fibra e conseqüentemente a ingestão de MS. Os fatores citados acima permitiram aos animais do grupo controle apresentarem ganho compensatório, igualando o GMD com os tratamentos suplementados. No último período ocorreram menores ganhos para os tratamentos controle e Supl. 2 em relação aos tratamentos Supl.1 e leucena. O fato do GMD do grupo Supl.2 ser igual ao grupo controle, pode ter ocorrido devido ao aumento do teor de proteína da pastagem nos dois últimos períodos (Figura 3 ), e os animais suplementados provavelmente estarem depositando maiores quantidades de tecido adiposo, havendo diminuição das exigências em proteína e aumento da de energia.

Tabela 14. Ganhos médios diários nos diferentes períodos experimentais para os diferentes tratamentos.

\begin{tabular}{lccccc}
\hline Tratamentos & \multicolumn{5}{c}{ GMD (Kg/dia) } \\
\hline & Período 1 & Período 2 & Período 3 & Período 4 & Período 5 \\
\hline \multirow{3}{*}{ Controle } & Julho & Agosto & Setembro & Outubro & Novembro \\
\cline { 2 - 6 } Leucena & $-0,371^{\mathrm{a}}$ & $-0,465^{\mathrm{a}}$ & $-0,165^{\mathrm{a}}$ & $1,025^{\mathrm{a}}$ & $0,545^{\mathrm{a}}$ \\
Supl.1 & $-0,153^{\mathrm{b}}$ & $0,354^{\mathrm{b}}$ & $0,639^{\mathrm{b}}$ & $0,998^{\mathrm{a}}$ & $0,804^{\mathrm{b}}$ \\
Supl.2 & $0,216^{\mathrm{c}}$ & $0,455^{\mathrm{b}}$ & $0,592^{\mathrm{b}}$ & $1,104^{\mathrm{a}}$ & $0,822^{\mathrm{b}}$ \\
& $0,284^{\mathrm{c}}$ & $0,384^{\mathrm{b}}$ & $0,796^{\mathrm{b}}$ & $0,999^{\mathrm{a}}$ & $0,602^{\mathrm{a}}$ \\
\hline
\end{tabular}

*Valores seguidos de letras diferentes diferem estatisticamente $(P \leq 0,05)$ 


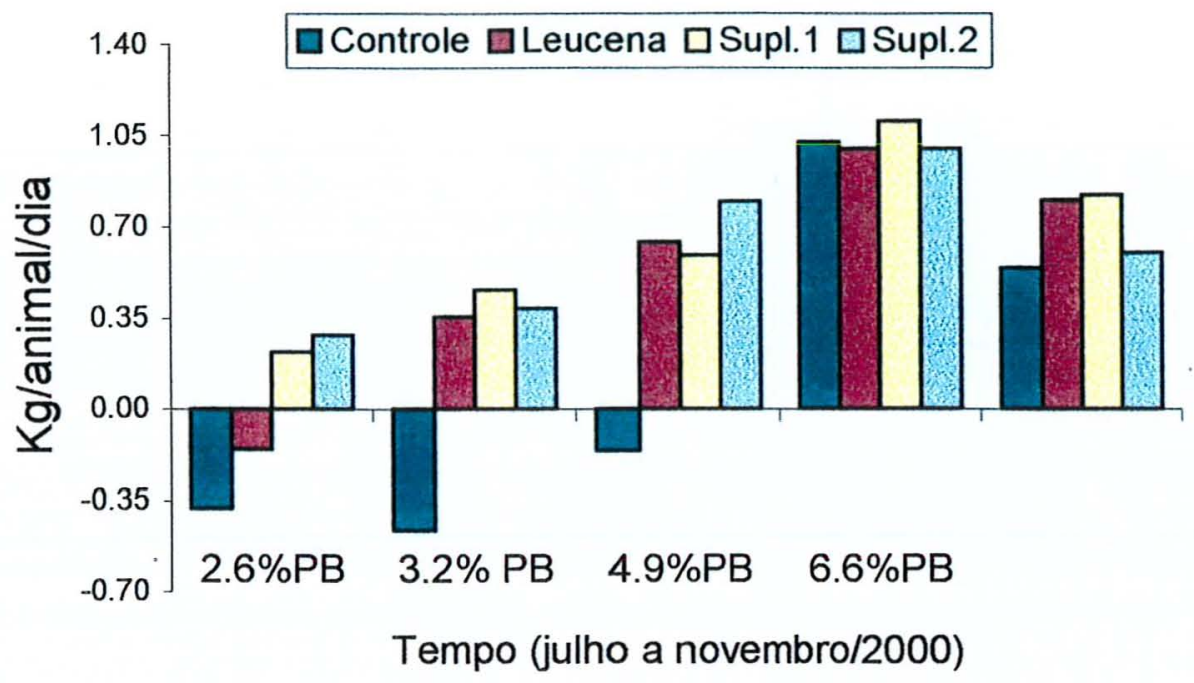

Figura 3 - Ganhos médios diários e teores de PB nos diferentes períodos experimentais para os diferentes tratamentos.

Como conseqüência das diferenças em ganho de peso, os tratamentos diferiram significativamente $(P \leq 0,05)$ em relação ao peso vivo final (Figuras 4 e 5 ), sendo superiores os animais dos tratamentos leucena, Supl.1 e 2 em relação ao tratamento controle. 
$\rightarrow-$ Controle $\rightarrow$ Leucena $\rightarrow$ Supl.1 $\rightarrow$ Supl.2

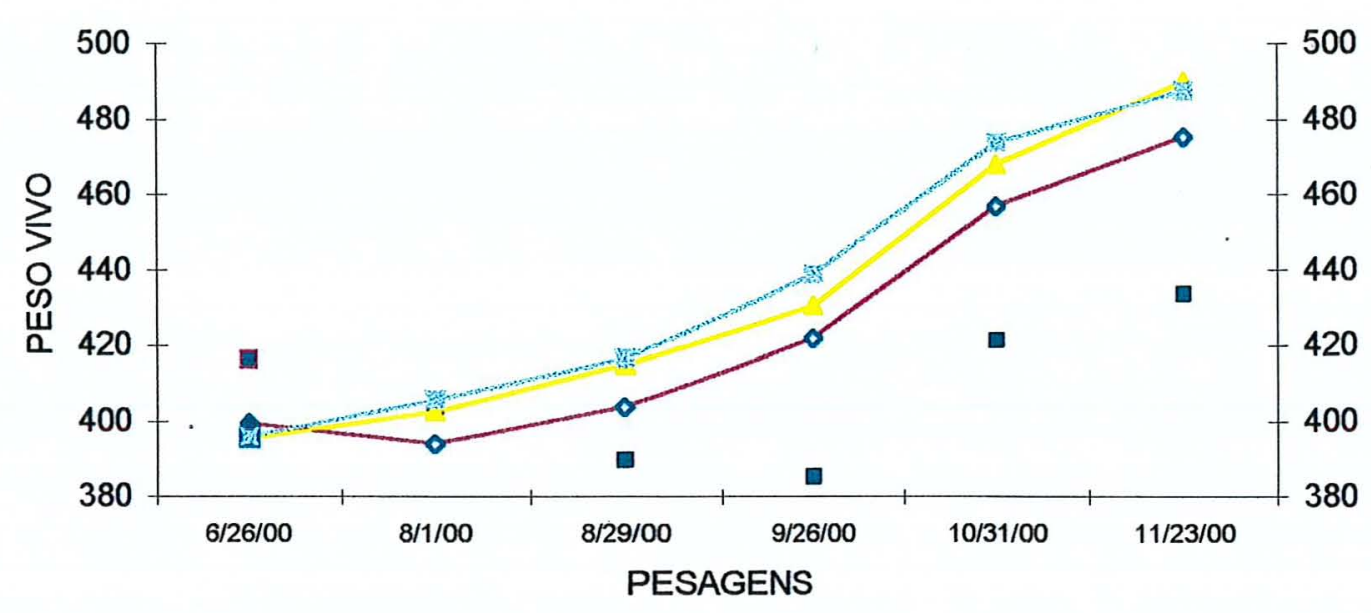

Figura 4 - Desempenho de bovinos Nelore em terminação com diferentes suplementos alimentares.

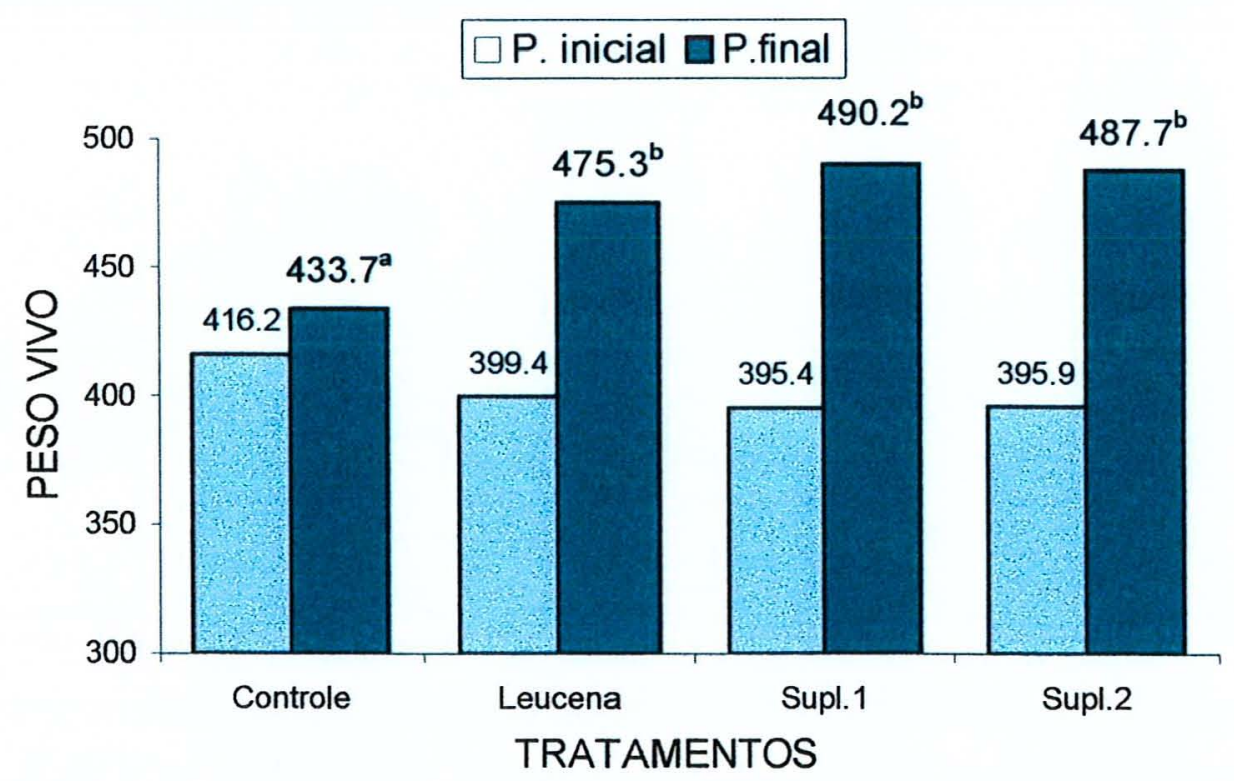

Figura 5 - Peso vivo final de bovinos Nelore em terminação com diferentes suplementos alimentares. 
A suplementação interferiu diretamente no ganho de peso dos animais, e conseqüentemente na produção por área. Os valores são apresentados na Figura 6.

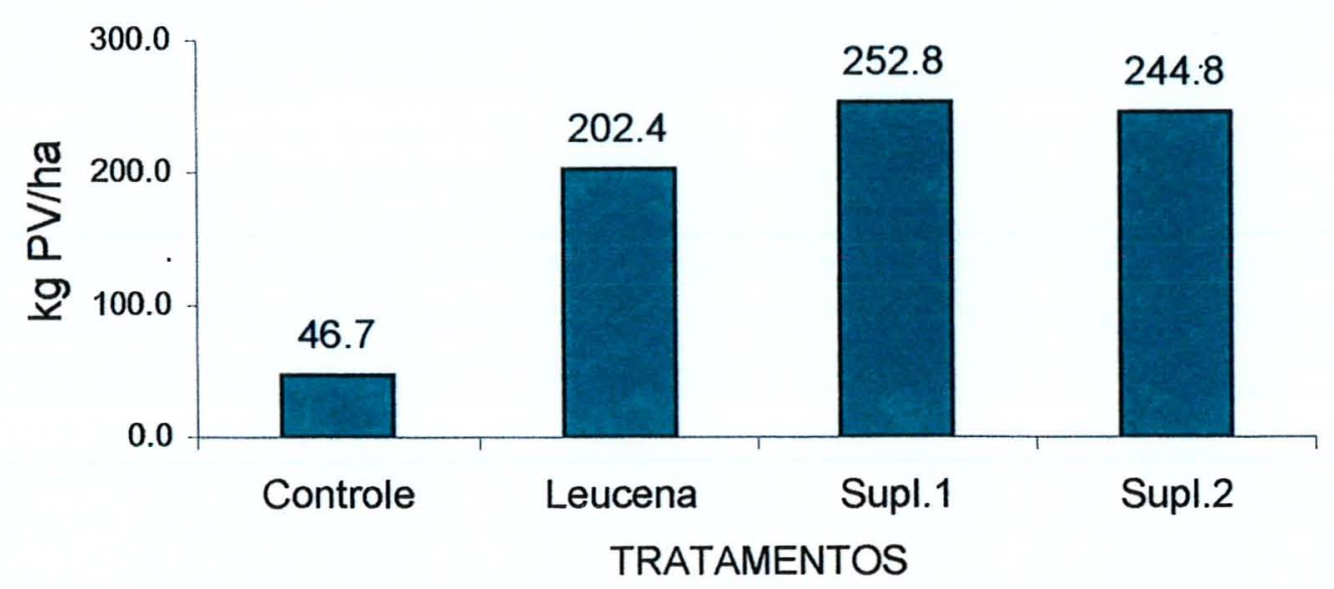

Figura 6 - Produção por área de bovinos Nelore em terminação com diferentes suplementos alimentares.

\subsection{Avaliações de carcaça}

\subsubsection{Rendimento de carcaça}

Devido à necessidade de comercialização dos animais e exigência das indústrias frigoríficas, foi definido o peso vivo mínimo de $440 \mathrm{Kg}$ para que o animal fosse abatido. Em virtude disso, as proporções de animais abatidos de cada tratamento foram diferentes (Tabela 15). A suplementação alimentar mais que dobrou o número de animais a serem abatidos em relação ao controle. Dos 32 animais existentes em cada tratamento, foram abatidos 13 animais do tratamento controle, 25 do leucena, 28 do Supl. 1 e 30 do Supl.2. 
Os rendimentos de carcaça foram superiores $(P \leq 0,05)$ para os animais suplementados, provavelmente devido à maior quantidade de gordura presente nas carcaças desses animais em relação a dos animais controle (Tabela 15).

O tecido adiposo é o componente mais variável dentre os tecidos constituintes da carcaça, sendo os músculos e ossos valores mais constantes. A quantidade de gordura na carcaça pode ser manipulada através da alimentação, tendo grande influência no rendimento de carcaça.

Tabela 15. Avaliações nas carcaças e porcentagem de animais abatidos nos diferentes tratamentos.

\begin{tabular}{lcccc}
\hline Tratamentos & \multicolumn{4}{c}{ Parâmetros } \\
\cline { 2 - 5 } & $\mathrm{PV}(\mathrm{Kg})$ & $\mathrm{PC}(\mathrm{Kg})$ & $\mathrm{RC}(\% \mathrm{PV})$ & $\%$ Abatidos \\
\hline Controle & $458,0^{\mathrm{a}}$ & $247,0^{\mathrm{a}}$ & $53,9^{\mathrm{a}}$ & 41,0 \\
Leucena & $487,0^{\mathrm{b}}$ & $271,0^{\mathrm{b}}$ & $55,6^{\mathrm{b}}$ & 78,0 \\
Supl.1 & $496,0^{\mathrm{b}}$ & $276,0^{\mathrm{b}}$ & $55,6^{\mathrm{b}}$ & 90,3 \\
Supl.2 & $493,0^{\mathrm{b}}$ & $278,0^{\mathrm{b}}$ & $56,4^{\mathrm{b}}$ & 94,0 \\
\hline
\end{tabular}

$\mathrm{PV}=$ peso vivo

$\mathrm{PC}=$ peso carcaça quente

$R C=$ rendimento de carcaça quente

$E G=$ espessura de gordura de cobertura após resfriamento

*alores seguido de letras diferentes diferem estatisticamente entre si $(P \leq 0,05)$

\subsubsection{Espessura de gordura de cobertura após resfriamento}

As medidas de espessura de gordura de cobertura, avaliadas após resfriamento na altura da $12^{a}$ costela, foram maiores para os animais Supl.1 e 2. Os animais dos tratamentos leucena e controle não diferiram entre si, e apesar de apresentarem menor espessura de gordura de cobertura, atingiram $3 \mathrm{~mm}$ que é a quantidade mínima necessária para se evitar problemas no resfriamento.

Ao analisarmos a espessura de gordura em relação a $100 \mathrm{Kg}$ de carcaça, não foi observada diferença significativa $(P \leq 0,05)$ entre os tratamentos (Tabela 16). A quantidade a mais de gordura está relacionada ao maior peso vivo dos animais, ou seja, os animais suplementados tiveram 
maiores GMD, iniciando a deposição de gordura há mais tempo que os animais controle em relação ao dia do abate.

Tabela 16. Espessura de gordura de cobertura de bovinos em terminação com diferentes suplementos.

\begin{tabular}{lcc}
\hline Tratamentos & $\begin{array}{c}\text { EG resfriada } \\
(\mathrm{mm})\end{array}$ & $\begin{array}{c}\text { EG/100 Kg carcaça } \\
(\mathrm{mm})\end{array}$ \\
\hline Controle & & \\
Leucena & $3,30^{\mathrm{a}} \pm 0,20$ & $1,34^{\mathrm{a}} \pm 0,08$ \\
Supl.1 & $4,24^{\mathrm{ab}} \pm 0,31$ & $1,56^{\mathrm{a}} \pm 0,10$ \\
Supl.2 & $4,75^{\mathrm{b}} \pm 0,33$ & $1,73^{\mathrm{a}} \pm 0,12$ \\
\multicolumn{2}{c}{ *Valores seguidos de letras diferentes diferem estatisticamente $(\mathrm{P} \leq 0,05)$} & $1,76^{\mathrm{a}} \pm 0,14$ \\
\hline
\end{tabular}

\subsection{Avaliações através de ultra-sonografia}

\subsubsection{Espessura de gordura de cobertura (EGultr)}

As avaliaçōes da espessura de gordura de cobertura através de ultrasonografia não diferiram estatisticamente $(P \leq 0,05)$, não demonstrando diferença na quantidade de gordura entre os animais suplementados ou não (Tabela 17).

Tabela 17. Espessura de gordura de cobertura avaliada através de ultrasonografia nos diferentes tratamentos.

\begin{tabular}{lcc}
\hline Tratamentos & $\begin{array}{c}\text { EG ultra-som } \\
(\mathrm{mm})\end{array}$ & $\begin{array}{c}\text { EGultr/100 Kg carcaça } \\
(\mathrm{mm})\end{array}$ \\
\hline Controle & & \\
Leucena & $3,30^{\mathrm{a}} \pm 0,20$ & $1,53^{\mathrm{a}} \pm 0,22$ \\
Supl.1 & $4,24^{\mathrm{ab}} \pm 0,31$ & $1,52^{\mathrm{a}} \pm 0,12$ \\
Supl.2 & $4,75^{\mathrm{b}} \pm 0,33$ & $1,32^{\mathrm{a}} \pm 0,09$ \\
\hline \multicolumn{2}{c}{ *Valores seguidos de letras diferentes diferem estatisticamente $(P \leq 0,05)$} & $1,46^{\mathrm{a}} \pm 0,13$ \\
\hline
\end{tabular}

Os valores de espessura de gordura medidos através do ultra-som, não apresentaram uma boa correlação $\left(R^{2}=0.013\right)$ com os valores medidos diretamente na carcaça após resfriamento (Figura 7). Alguns aspectos, como 
a quantidade de gordura presente nos animais a serem avaliados, influem na precisão das medidas obtidas com ultra-som. No nosso trabalho, os animais apresentavam pouca quantidade de gordura de cobertura, o que pode ter sido um dos fatores para a baixa correlação obtida. A menor espessura de gordura dos animais, pode ter influenciado os valores de ultra-som, apesar da ultra-sonografia tender a superestimar medidas com menores espessuras de gordura e subestimar maiores espessuras (Charagu et al., 2000). Outros trabalhos da literatura também não encontraram boas correlações entre essas medidas. Entretanto, os trabalhos de Silva et al. (2001) e Suguisawa et al. (2001) mostraram correlaçōes com $\mathrm{R}^{2}=0,76$ e 0,79 respectivamente, entre as medidas obtidas através da ultra-sonografia e os valores medidos diretamente na carcaça após resfriamento, definindo a ultra-sonografia como um bom método para avaliação da gordura de cobertura. Os trabalhos citados acima apresentaram médias de 8,50 e $6,00 \mathrm{~mm}$ de gordura na medida direta respectivamente, sendo que em ambos, as medidas com ultrasom subestimaram a quantidade real. 


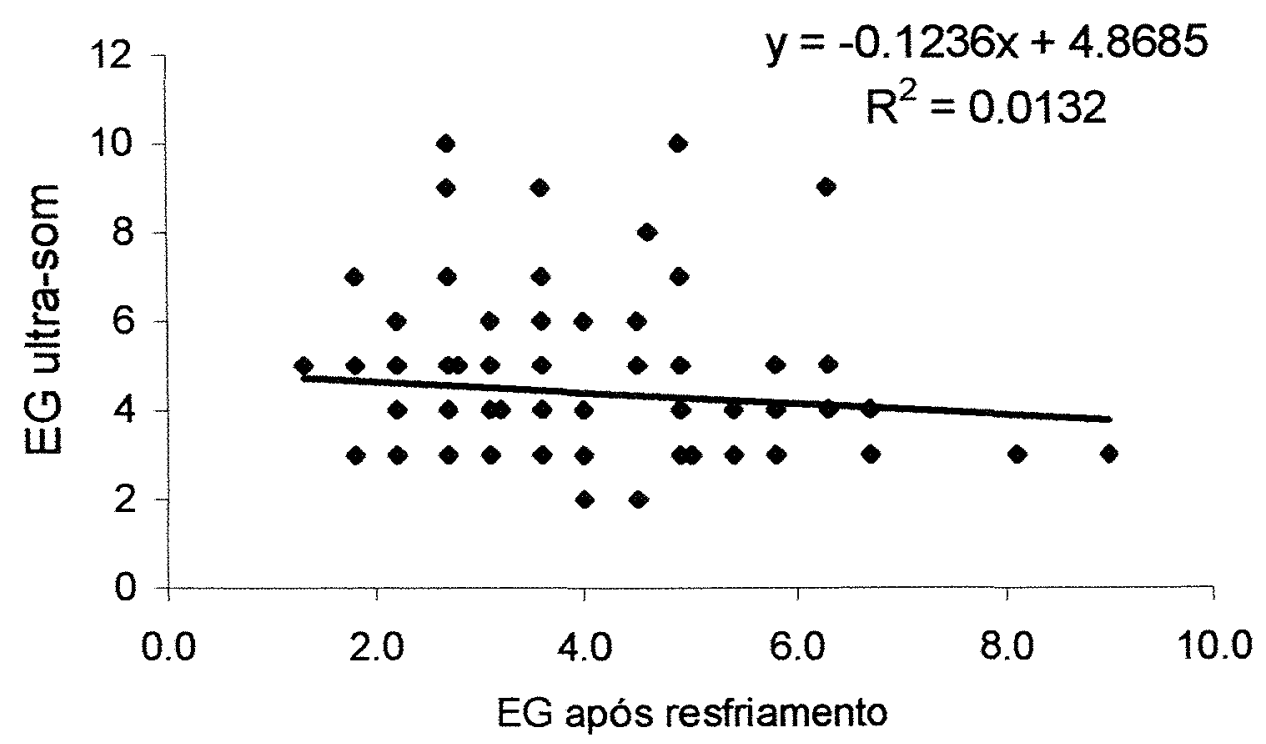

Figura 7 - Correlação entre os valores de espessura de gordura avaliados através de ultra-sonografia in vivo e medida direta na carcaça na altura da $12^{\mathrm{a}}$ costela após resfriamento.

\subsection{2 Área de olho de lombo (AOL)}

A AOL é uma importante característica zootécnica por apresentar correlação positiva com a musculosidade da carcaça e o rendimento de cortes.

AOL é fortemente influenciada pelo peso da carcaça, portanto para comparação de $\mathrm{AOL}$ entre animais, utiliza-se à relação de $\mathrm{AOL}\left(\mathrm{cm}^{2}\right)$ por $100 \mathrm{Kg}$ de carcaça.

As medidas de $A O L / 100 \mathrm{Kg}$ de carcaça, foram maiores $(P \leq 0,05)$ para os animais controle, em relação aos demais (Tabela 18). Esses resultados não seriam esperados, pois os animais eram oriundos de um mesmo rebanho e dificilmente $o$ aspecto nutritivo mudaria significativamente essas medidas. O aspecto nutritivo tem grande potencial para alterar as quantidades de gordura da carcaça, sendo as quantidades de músculo mais intensamente influenciadas pelo fator genético. 
Apesar dos animais serem de mesma origem e com idades semelhantes, ao fixarmos um peso mínimo de abate de $440 \mathrm{Kg}$ de peso vivo, houve tendência para seleção de animais de maior tamanho corporal no tratamento com menor proporção de animais abatidos (controle). $O$ fato de não haver diferença estatística entre os valores absolutos das $A O L$, nos reforça a idéia de ter ocorrido o que foi descrito acima.

Tabela 18. Área de olho de lombo de bovinos em terminação com diferentes suplementos alimentares.

\begin{tabular}{lcc}
\hline Tratamentos & $\begin{array}{c}\mathrm{AOL} \\
\left(\mathrm{cm}^{2}\right)\end{array}$ & $\begin{array}{c}\text { AOU } 100 \mathrm{Kg} \text { carcaça } \\
\left(\mathrm{cm}^{2}\right)\end{array}$ \\
\hline Controle & & \\
Leucena & $59,25^{\mathrm{a}}$ & $24,04^{\mathrm{a}}$ \\
Supl.1 & $57,53^{\mathrm{a}}$ & $21,41^{\mathrm{b}}$ \\
Supl.2 & $57,23^{\mathrm{a}}$ & $20,57^{\mathrm{b}}$ \\
\multicolumn{2}{c}{ *Valores seguidos de letras diferentes diferem estatisticamente $(\mathrm{P} \leq 0,05)$} & $20,70^{\mathrm{b}}$ \\
\hline \multicolumn{2}{c}{}
\end{tabular}

Não foram feitas medidas diretas da $\mathrm{AOL}$, pois seria necessário o corte das carcaças para essa avaliação, o que danificaria as mesmas impedindo a comercialização. A avaliação direta da $A O L$ é feita na altura da $12^{\mathrm{a}}$ costela, sendo necessário o corte do músculo Longissimus dorsi nessa região, ao contrário do corte que é feito para comercialização, entre a $5^{\mathrm{a}}$ e $6^{\mathrm{a}}$ costelas. 


\section{Conclusões}

- Suplementação de bovinos em terminação com $0,3,0,6$ ou $0,7 \%$ peso vivo/cabeça/dia, não alterou significativamente os parâmetros de fermentação ruminal.

- A utilização de subprodutos agroindustriais, como a polpa cítrica e o refinazil $^{\circledR}$ úmido, para suplementação de bovinos em terminação a pasto, proporcionou bom desempenho possibilitando redução da idade de abate.

- A suplementação energético/protéica permite o aumento do GMD de bovinos terminados a pasto, e conseqüentes aumento de produção por área.

- Houve aumento no rendimento de carcaça dos animais suplementados a pasto em relação aos não suplementados. 


\section{REFERÊNCIAS BIBLIOGRÁFICAS}

ALBRO, J. D.; WEBER, D.W.; DELCURTO, T. Comparison of whole, raw soybeans, extruded soybeans, or soybean meal and barley on digestive characteristics and performance of weaned beef steers consuming mature grass hay. Journal of Animal Science, v. 71, n. 1, p. 26-32. 1993

ALLEONI, G.F.; LEME, P.R.; BOIN, C.; BEISMAN, D.A. Utilização do refinazil úmido em substituição a um concentrado de milho com farelo de algodão em rações de confinamento. Boletim da Indústria Animal,

v. 47, n.1, p. $67-71,1990$.

ANDRADE, P; ALCALDE, C. R. Nutrição e alimentação de novilho precoce. In: ENCONTRO NACIONAL SOBRE NOVILHO PRECOCE. Campinas, 1995. Anais. Campinas: CATI, 1995. p. 93-109.

ASSOCIATION OF ANALYTICAL CHEMISTS. Official methods of analysis. 15 ed. Washington, 1990. v. 1

BANDYK, C.A.; COCHRAN, R.C.; WICKERSHAM, E.C.; TITGEMEYER, E.C.; FARMER, C.G.; HIGGINS, J.J. Effect of ruminal vs postruminal administration of degradable protein on utilization of low quality forage by beef steers. Journal of Animal Science, v. 79, n. 1, p. 225-231, 2001.

BERGMAN, E.N. Energy contributions of volatile fatty acids from the gastrointestinal tract in various species, Physiological Reviews, v. 70 , n.2, p. 567-590, 1990. 
BODINE, T.N.; PURVIS, H.T., ACKERMAN, C.J.; GOAD, C.L. Effects of supplementing prairie hay with corn and soybean meal on intake, digestion, and ruminal measurements, by beef steers. Journal of Animal Science, v. 78, n. 13, p. 3144-3154, 2000.

BOIN, C.; ALLEONI, G.F.; BEISMAN, D.A. Fibra úmida do grão de milho na alimentação animal, Comunicação Científica. FACULDADE DE MEDICINA VETERINÁRIA E ZOOTECNIA DA UNIVERSIDADE DE SÃO PAULO, v. 9, n. 2, p. 181-187, 1985.

BOWLING, R.A.; SMITH, G.C.; CARPENTER, Z.L.; DUTSON, T.R.; OLIVER, W.M. Comparison of forage-finished ad grain-finished beef carcass. Journal of Animal Science, v. 45, n. 1, p. 209-215, 1977.

CANTON, J. S.; DHUYVETTER, D. V. Influence of energy supplementation on grazing ruminants: requirements and responses. Journal of Animal Science, v. 75, n. 3, p. 533-542, 1997.

CARVALHO, M. P. Polpa cítrica peletizada na alimentação de bovinos de corte em confinamento. Revista Pecuária de Corte, n. 70, p. 93-97, 1997.

CARVALHO, M. P. Substituição do milho por subprodutos energéticos em dietas de bovinos à base de bagaço de cana tratado à pressåo e vapor: digestibilidade e parâmetros ruminais. Piracicaba, 1998. 120p. Dissertação (Mestrado) - Escola Superior de Agricultura "Luiz de Queiroz", Universidade de São Paulo.

CHANEY, A.L.; MARBACH, E.P. Modified reagents for determination of urea and ammonia. Clinical Chemistry, v. 8, n. 2, p. 130-132, 1962.

CHARAGU, P.K.; CREWS, D.H.; KEMP, R.A.; MWANSA, P.B. Machine effects on accuracy of ultrasonic prediction of backfat and ribeye area in beef bulls, steers and heifers. Canadian journal of Animal Science, v. 80, n. 1, p. $19-24,2000$. 
DEMARCHI, J.J.A.A.; POZZI, C.R.; ARCARO JÚNIOR, I.; GERDES, L.; FELTRIN, E. Análise qualitativa e de conservação do farelo de milho úmido ("wet corn glúten feed"). In: REUNIÃO ANUAL DA SOCIEDADE BRASILEIRA DE ZOOTECNIA, 35., Botucatu, 1998. Anais. Botucatu: SBZ, 1998. v. 2, p. 275-277.

DRIEDGER, L.J.; LOERCH, S.C. Effects of protein concentration and source on nutrient digestibility by mature steers limit-fed high concentrate diets. Journal of Animal Science, v. 77, p. 960-966, 1999.

ELGERSMA, A.; OERLEMANS, J.F.; COATES, D.B. The effect of browse species when fed as a supplement to low quality native grass hay on animal performance. In: INTERNATIONAL GRASSLANDS CONGRESS, 19., São Pedro, Brasil, 2001. Anais. Piracicaba: FEALQ, 2001. p. $712-$ 713.

ELIZALDE, J.C.; CREMIN, J.D.; FAULKNER, D.B.; MERCHEN, N.R. Performance and digestion by steers grazing tall fescue and supplemented with energy and protein. Journal of Animal Science, v. 76, p. 1691-1701, 1998.

EUCLIDES, V.P.B.; EUCLIDES FILHO, K.; FIGUEIREDO, G. R. ; OLIVEIRA, M.P. Suplementação para produção de bovinos de corte. In: REUNIĀO ANUAL DA SOCIEDADE BRASILEIRA DE ZOOTECNIA, 34., Juiz de Fora, 1997. Anais. Juiz de Fora: SBZ, 1997. v. 2, p. 249.

EUCLIDES, V.P.B.; EUCLÍDES FILHO, K.; ARRUDA, Z. J.; FIGUEIREDO, G. R. Desempenho de novilhos em pastagens de Brachiaria decumbens submetidos a diferentes regimes alimentares. Revista da Sociedade Brasileira de Zootecnia. v. 27, n. 2, p. 246-254. 1998.

FERNANDES, V.G. Co-produtos da industrialização do milho. In: SIMPÓSIO DE NUTRIÇÃO ANIMAL, - BOVINOS LEITEIROS, 1998. Anais. Nova Odessa: Instituto de Zootecnia, 1999. p. 117-130. 
FREEMAN, A.S.; GALYEAN, M.L.; CATON, J.S. Effects of supplemental protein percentage and feeding level on intake, ruminal fermentation, and digesta passage in beef steers fed prairie hay. Journal of Animal Science, v. 70, n. 5, p. 1562-1572, 1992.

GARCÉS-YÉPES, P.; KUNKLE, W. E.; BATES D. B.; MOORE, J. E.; THATCHER, W. W.; SOLLENBERGER L.E. Effects of supplemental energy source and amount of forage intake and diet digestibility by sheep. Journal of Animal Science, v. 75, n. 7, p. 1918-1925, 1997.

GIRALDO, M.A.M. Estratégias para avaliação nutricional da polpa cítrica seca em suínos em terminação. Belo Horizonte, 1999. 95p. Tese (Doutorado) - Escola de Veterinária, Universidade Federal de Minas Gerais.

GRIEBENOW, R.L.; MARTZ, F.A.; MORROW, R.E. Forage based beef finishing systems: a review. Journal of Production Agriculture, v. 9, n. 1, p. 84-91, 1997.

GRINGS, E.E.; SHORT, R.E.; ADAMS, D.C. Effects of growth potential supplementation on steers grazing fall pasture in the northern great plains. Journal of Production Agriculture, v. 10, n. 2, p. 241-245, 1997.

HADDAD, C. M.; CASTRO, F. G. F. Suplementação Mineral e Novilhos Precoces - Uso de sais proteinados e energéticos na alimentação. In: SIMPÓSIO SOBRE PRODUÇÃO INTENSIVA DE GADO DE CORTE, Piracicaba, 1998. Anais. Piracicaba: FEALQ, 1998. p. 188-222.

HAFFLEY, J. L.; ANDERSON, B. E.; KLOPFENSTEIN, T. J. Supplementation of growing cattle grazing warm season grass with protein of various ruminal degradabilities. Journal of Animal Science, v. 71, n. 2, p. 522-529. 1993.

HAMMOND, A.C. High "BUN" level a sign of protein waste. Agricultural Research, Apr. 1994. 
HENNESSY D. W.; WILLIAMSON, P. J.; NOLAN, J. V. et al. The roles of energy rich or protein rich supplements in the subtropics for young cattle consuming basal diets that are low in digestible energy and protein. Journal of Agricultural Science, v. 100, n. 3, p. 657-666, 1983.

HENNESSY, D.W.; KOHUN, P.J.; WILLIAMSON, P.J.; BROWN, D.A.; NOLAN, J.V. The effect of nitrogen and protein supplementation on feed intake, growth and digestive function of steers with different Bos taurus genotypes when fed a low quality grass hay. Australian Journal of Research, v. 46, n. 4, p. 1121-1136, 1995.

HERNÁNDES, D; HERNÁNDES, I.; HERNÁNDES, C. A.; CARBALLO, M.; CARNET, R.; MENDONZA, R.; MENDONZA, C.; RODRIGUES, N. Ceba de bovinos com Andropongon gayanus CIAT-621 complementado com un banco de proteina de Leucaena leucocephala y Neonotonia wightii. Pastos y Forrages, v. 15, n. 1, p. 153-163. 1992.

HESS, B.W.; SCHOLLJEDERGES, E.J.; COLEMAN, S.A.; WILLIAMS, J.E. Supplemental protein plus ruminally protected methionine and lysine for primiparous beef cattle consuming annual rye hay. Journal of Animal Science, v. 76, n. 6, p. 1767-1777, 1998.

HODGSON, J. Supplements. In: Grazing Management. New York: Longman Handbooks in Agriculture, 1990, cap. 14, p. 134-142.

HOOVER, W.H. Chemical factors involved in ruminal fiber digestion, Journal Dairy Science, v. 69, n. 10, p. 2755-2766, 1986.

KARGES, K.K.; KLOPFENSTEIN, T.J.; WILKERSON, V.A.; CLANTON, D.C. Effects of ruminally degradable and escape protein supplements on steers grazing summer native range. Journal of Animal Science, v. 70 , n. 7, p. 1957-1964, 1992.

KARN, J. Supplementation of yearling steers grazing northern great plains rangelands. Journal of Range Management, v. 53, n. 2, p. 170-175, 2000. 
KEANE, M.G.; ALLEN, P. Effects of production system intensity on performance, carcass composition and meat quality of beef cattle. Livestock Production Science, v. 56, n. 1, p. 203-214, 1998.

KNAUS, W. F.; BEERMANN, D. H., ROBINSON, T. F.; FOX D. G.; FINNERTY, K. D. Effects of dietary mixture of meat and bone meal, feather meal, blood meal, and fish meal on nitrogen utilization in finishing holstein steers. Journal of Animal Science, v. 76, n. 5, p. 1481-1487. 1998.

KOSTER, H.H.; COCHRAN, R.C.; TITGEMEYER, E.C.; VANZANT, E.S.; ABDELGADIR, I.; ST-JEAN, G. Effect of increasing degradable intake protein on intake and digestion of low-quality, tallgrass-prairie forage of beef cows. Journal of Animal Science, v. 74, n. 9, p. 2473-2481, 1996.

KRYSL, L.J.; HESS, B.W. Influence of supplementation on behavior of grazing cattle. Journal of Animal Science, v. 71, n. 9, p. 2546-2555, 1993.

LAKE, R. P.; CLANTON, D. C.; KARN, J. F. Intake, digestibility and nitrogen utilization of steers consuming irrigated pasture as influenced by limited energy supplementation. Journal of Animal Science, v. 38, n. 6, p. 1291-1297. 1974.

LAVEZZO, O.E.N.M. Influência de métodos de coleta de fluido ruminal sobre os parâmetros de fermentação, em bovinos alimentados com diferentes fontes de proteina. Piracicaba, 1986 167p. Dissertação (Mestrado) Escola Superior de Agricultura "Luiz de Queiroz", Universidade de São Paulo.

LENG,R.A.; NOLAN, J.V. Symposium: protein nutrition of the lactating dairy cow. Journal of Dairy Science, v. 67, n. 4, p. 1072-1084, 1984

LOURENÇO, J. A. Produção animal com leguminosas arbóreas/arbustivas. In: SIMPÓSIO SOBRE USOS MÚLTIPLOS DE LEGUMINOSAS ARBUSTIVAS ARBÓREAS, Nova Odessa, 1993. Anais. Nova Odessa: Instituto de Zootecnia, 1993. p. 131-146. 
LOURENÇO, A.J.; CARRIEL, J.M. Desempenho de bovinos nelore em pastagens de Brachiaria brizantha associados a Leucaena leucocephala. In: REUNIÃO ANUAL DA SOCIEDADE BRASILEIRA DE ZOOTECNIA, 39., Juiz de Fora, 1997. Anais. Juiz de Fora: SBZ, 1997. v. 2, p. 345-348

LOURENÇO, A.J.; LEME, P.R.; MANELLA, M.Q. Animal performance on Brachiaria brizantha alone or supplemented with concentrate or protein bank of Leucaena leucocephala. In: INTERNATIONAL GRASSLANDS CONGRESS, 19., São Pedro, 2001. Anais. Piracicaba: FEALQ, 2001. p. $699-700$.

LUCHIARI FILHO, A. Pecuária da carne bovina. São Paulo: s. ed., 2000, $135 p$.

LUCHIARI FILHO, A.; PEDREIRA, A.C.M.S. Manejo nutricional $\times$ Qualidade da came. In: WORKSHOP: EFEITOS DO MANEJO PRÉ-ABATE NA QUALIDADE DA CARCAÇA E DA CARNE BOVINA. Anais. Campinas: s. ed., 2000.

LUDDEN, P. A.; JONES, J. M.; CECAVA, M. J.; HENDRIX, K. S. Supplemental protein sources for steers fed corn-based diets: II. Growth and estimated metabolizable amino acids supply. Journal of Animal Science, v. 73, n. 5, p. 1476-1486. 1995.

MANDELL, I.B.; GULLET, E.A.; BUCHANAN-SMITH, J.G.; CAMPBELL, C.P. Effects of diet and slaughter on carcass composition and beef quality in charolais cross steers. Canadian Journal of Animal Science, v. 77, n. 2, p. 403-414, 1997.

MANELLA, M. Q. Parâmetros ruminais e desempenho de bovinos Nelore em pastos de Brachiaria brizantha cv marandu recebendo suplemento protéico ou com livre acesso a banco de proteína de Leucaena leucocephala cv cunnigham. Pirassununga, 2000. 75p. Dissertação (Mestrado) - Faculdade de Medicina Veterinária e Zootecnia, Universidade de São Paulo. 
MATHIS, C.P.; COCHRAN, R.C.; STOKKA, G.L.; HELDJT, J.S.; WOODS, B.C.; OLSON, K.C. Journal of Animal Science, v. 77 , n. 11, p. 31563162, 1999.

MBONGO, T.; POPPI, D. P.; WINTER, W. H. The liveweight gain response of cattle grazing Setaria sphacelata pastures when supplemented with formaldehyde treated casein - abstract. Australian Society of Animal Production, v. 20, n. 2, p. 342, 1994.

MINSON, D.J. Forage in ruminant nutrition. San Diego: Academic Press, 1990, cap. 2, p. 9-58.

MOSS, R.J.; MURRAY, R.M. Rearing dairy calves on irrigates tropical pastures 1. Effect of protein level on liveweight gain and blood components. Australian Joumal of Experimental Agriculture, v. 32, p. 569-579, 1992.

NATIONAL RESEARCH COUNCIL (N.R.C.). Nutrient requeriments of beef cattle. 7. ed. Washington: National Academy Press, 1996. 232 p.

OLIVEIRA, M.D.S.; SAMPAIO, A.A.M.; VIEIRA, P.F.; FREITAS, J.C.M.; SHOKEN-ITURRINO, R.P. Efeito de métodos de coleta de fluido ruminal $\mathrm{m}$ bovinos sobre alguns parâmetros ruminais e microbiológicos. Pesquisa Agropecuária Brasileira, v. 34, n. 5, p. 867-871, 1999.

OLSON, K.C.; COCHRAN, R.C.; JONES, T.J.; VANZANT, E.S.; TITGEMEYER, E.C.; JOHNSON, D.E. Effects of ruminal administration of supplemental degradable intake protein and starch on utilization of low quality warn-season grass hay by beef steers. Journal Animal Science, v. 77, n. 4 , p. $1016-1025,1999$.

ORSKOV, E.R. Nutrición proteica de los ruminantes, Zaragoza: Academic Press, 1988. cap. 3, p. 43-94.

OWENS, F.N.; GOETSCH, A.L. Ruminal fermentation. In: $\mathrm{CHURCH,} \mathrm{D.C.}$ The ruminant animal. Prentice Hall: Waveland Press, 1988. cap. 8, p. 145-172. 
PALMIQUIST, D.; CONRAD, H. 1971. Origin plasma fatty acids in lactating cows fed high fat diets. Journal Dairy Science, v. 54, n. 7, p. 10251031.

PARSONS, S.D.; ALLISON, C.D. Grain management as it effects nutrition, animal production and economics of beef production. Veterinary Clinics of North America. Food Animal Practice, v. 7 , n. 12, p. 3551-3561, 1991.

PATE, F. M.; BROWN, W. F.; HAMMOND, A. C. Value of feather meal in a molasses-based liquid supplement fed to yearling cattle consuming a forage diet. Journal Animal Science, v. 73, n.10, p. 2865-2872, 1995.

PATERSON, J.A.; BELYEA, R.L.; BOWMAN, J.P. et al. The impact of forage quality and supplementation regimen on ruminant animal intake and performance. In: FAHEY Jr., G.C. (Ed.). Forage quality, evaluation, and utilization. Madison: American Society of Agronomy/Crop Science Society of America/Soil Science Society of America, 1994. cap. 2, p. 59114.

PAZIANI, S.F.; ANDRADE, P.; ALCADE, C.R. Efeito do suplemento no desempenho de bovinos em pastagens no período da seca. In: REUNIÃO ANUAL DA SOCIEDADE BRASILEIRA DE ZOOTECNIA, 35. Botucatu, 1998. Anais. Botucatu: SBZ, 1998. v. 2, p. 497-499.

PEREIRA, J.R.A. Efeito da suplementação protéica em pastagens de Brachiaria bryzantha cv. Marandu sobre a degradabilidade da forragem e parâmetros ruminais. Jaboticabal, 1997, 75p. Tese (Doutorado) Faculdade de Ciências Agrárias e Veterinárias, Universidade Estadual Paulista "Júlio de Mesquita Filho".

PEREIRA, J.R.A.; REIS, R.A.; RODRIGUES, L.R.A.; FREITAS, D. Effects of supplements on forage degradability of Brachiaria bryzantha $\mathrm{CV}$. Marandu grazed by steers. In: INTERNATIONAL GRASSLANDS CONGRESS, 19., São Pedro, 2001. Anais. Piracicaba: FEALQ, 2001. p. 696-670. 
PERUCHENA, C. A. Suplementación de bovinos para carne sobre pasturas tropicales, aspectos nutricionales, productivos y econômicos (compact disc). In: REUNIÃO DA SOCIEDADE BRASILEIRA DE ZOOTECNIA, 41., Porto Alegre, 1999. Anais (CD-Room). Porto Alegre: SBZ, 1999.

PETER, C.M.; FAULKNER, D.B.; MERCHEN, N.R.; PARRETT, D.F.; NASH, T.J.; DALQUIST, J.M. The effects of corn milling coproducts on growth performance and diet digestibility by beef steers. Journal of Animal Science, v. 78, n. 1, p. 1-6, 2000.

PETTY, S.R.; POPPI, D.P.; TRIGLONE, T. Effect of maize supplementation, seasonal temperature and humidity on the liveweight gain of steers grazing irrigated Leucaena leucocephala / Digitariaerantha pastures in north-west Australia. Journal of Agricultural Science, v. 130, n. 1, p. 95-105, 1998.

POPPI, D.P.; MCLENNAN, S.R. Protein and energy utilization by ruminants at pasture. Journal of Animal Science, v. 73, n.1, p. 278-290, 1995.

PORDOMINGO, A. J.; WALLACE, J. D.; FREEMAN, A. S.; GALYEAN, M. L. Journal of Animal Science, v. 69, n. 6, p. 1678-1687, 1991.

POSSENTI, R.A.; MELOTTI, L.; BRAUN, G.; CASTRO, A.L.; ARCARO, J.P.; FAVA, C.D. Degradabilidade ruminal da fibra do grão de milho (refinazil) em dietas contendo diferentes níveis do produto. Boletim da Indústria Animal, v. 55, n. 1, p. 19-30, 1998.

QUEIROZ, A.C.; BARBOSA, M.A.; RESENDE, F.D.; PEREIRA, J.C.; DUTRA, A.R. Suplementação da palhada de milho na alimentação de bovinos. 2. Concentração de amônia ruminal e pH ruminal. Revista da Sociedade Brasileira de Zootecnia. v. 27, n. 2, p. 390-396, 1998.

RAMOS, J.A.; MENDONZA M.; ARANDA, E.; GARCIA-BOJALIL C.; BARCENA R.; ALANIS, J. Escape protein supplementation of growing steers grazing stargrass. Animal feed Science Technology, v. 70, n. 1 , p. 249-256, 1998. 
REIS, R.A.; RODRIGUES, L.R.de.A.; PEREIRA, J.R.A. A Suplementação como estratégia de manejo de pastagem. In: SIMPÓSIO SOBRE O MANEJO DA PASTAGEM, 13., Piracicaba, 1996. Anais. Piracicaba: FEALQ, 1997. p. 123-151.

RENNÓ, L.N.; VALADARES, R.F.D.; VALADARES FILHO, S.C.; SILVA, J.F.C.; CECON, P.R.; GONÇALVES, L.C.; DIAS, H.L.C.; LINHARES, R.S. Concentração plasmática de uréia e excreção de uréia e creatina em novilhos. Revista da Sociedade Brasileira de Zootecnia. v.29, n. 4, p. $1235-1243,2000$.

RICHARDS, C. J.; STOCK, R.A.; KLOPFENSTEIN, T.J.; SHAIN, D.H. Effect of wet corn gluten feed, supplemental protein, and tallow on steers finishing performance. Journal of Animal Science, v. 76, n. 2, p. 421$428,1998$.

RIORDAN, E.G.O.; FRENCH, P.; MOLONEY, A.P. Intake and growth of steers offered different allowances of autumn grass and concentrates. In: INTERNATIONAL GRASSLANDS CONGRESS, 19., São Pedro, 2001. Brasil. Anais. Piracicaba: FEALQ, 2001. p. 709-710.

ROBERTSON, J.B.; VAN SOEST, P.J. The detergent system of analysis and its application to human foods. In: JAMES, W.P.T.; THEANDER, O. The analysis of dietary fiber in food. New York: Marcel Dekker, 1981., cap. 6, p. 123-158.

ROCHA FILHO, R. R.; MACHADO, P. F.; D'ARCE, R. D.; FRANCISCO Jr., J. C. Polpa de citros e de milho e a produção de ácidos graxos voláteis no rúmen. Scientia Agricola, v. 56, n. 2, p. 471-477, 1999.

ROSENBERGER, G. Exame clínico dos bovinos. 2. ed. São Paulo: Guanabara Koogan, 1987. 408p. 
RUAS, J.R.M.; TORRES, C.A.A.; VALADARES FILHO, S.C.; PEREIRA, J.C.; BORGES, L.E.; MARCATI NETO, A. Efeito da suplementação protéica a pasto sobre consumo de forragens, ganho de peso e condição corporal, em vacas Nelore. Revista da Sociedade Brasileira de Zootecnia. v. 29 , n. 3, p. 930-934, 2000.

RUIZ, T.E., FEBLES, G., CASTILLO, E., BERNAL, G., DIAZ, L.E. Grassland performance with Leucaena leucocephala protein banks associated with guinea grass under two stocking rates with fattening cattle. Cuban Journal of Agriculture Science, v. 29, p. 355-360, 1995.

RUSSEL, J.B.; O'CONNOR, J.D.; FOX, D.G.; SNIFFEN, C.J.; VAN SOEST, P.J. A net carbohydrate and protein system for evaluation cattle diets, I Ruminal fermentation, Journal of Animal Science, v. 70 , n. 12, p. 35513561, 1992.

SANSON, D.W.; CLANTON, D.C.; RUSH, I.G. Intake and digestion of low quality meadow hay by steers and performance of cows on native range when feed protein supplements containing various levels of corn. Journal of Animal Science, v. 68, n. 2, p. 595-603, 1990.

SANTOS, F.A.P.; SANTOS, J.E.P.; THEURER, C.B. HUBER, J.T. Effects of rumen-undegradable protein on dairy cow performance: A 12-year literature review. Journal of Dairy Science, v. 81 , n. 11, p. 3182-3213, 1998.

SHAIN, D.H.; STOCK, R.A.; KLOPFENSTEIN, T.J.; HEROLD, D.W. Effect of degradable intake protein level on finishing cattle performance and ruminal metabolism. Journal of Animal Science, v. 76, n. 1, p. 242-248, 1998.

SILVA, S.L.; LEME, P.R.; FIGUEIREDO, L.G.G.; PEREIRA, A.S.C.; PUTRINO, S.M. Correlações entre características de carcaça obtidas in vivo por ultra-sonografia e na carcaça post mortem em novilhos Nelore. In: REUNIÃO ANUAL DA SOCIEDADE BRASILEIRA DE ZOOTECNIA, 38., Piracicaba, 2001. Anais. Piracicaba: FEALQ, 2001. p. 1206-1207. 
STATISTICAL ANALYSES SYSTEM. SAS User's guides: statistics. 5 ed., Cary, 1985.

SUGUISAWA, L.; OLIVEIRA, H.N.; MATTOS, W.R.S.; SILVEIRA, A.C.; ARRIGONI, M.D.B.; CHARDULO, L.A.L. Ultrassonografia em tempo real no modelo biológico de produção do superprecoce. In: CONGRESSO BRASILEIRO DE CIÊNCIA E TECNOLOGIA DE CARNES, São Pedro, 2001. Anais. Campinas: ITAL, 2001. p. 94-95.

TJARDES, K.E.; FAULKNER, D.B.; BUSKIRK, D.D.; PARRET, D.F.; BERGER, L.L.; MERCHEN, N.R.; IRELAND, F.A. The influence of processed corn and supplemental fat on digestion of limit-fed diets and performance of beef cows. Journal of Animal Science, v. $76, n .1$, p. 817, 1998.

VALADARES, R.F.D.; GONÇALVES, L.C.; RODRIGUEZ, N.M.; VALADARES FILHO, S.C.; SAMPAIO, I.B. Niveis de proteina em dietas de bovinos: 4 . Concentração de amônia ruminal e uréia plasmática e excreções de uréia e creatina. Revista da Sociedade Brasileira de Zootecnia. v. 26, n. 6, p. 1270-1278, 1997.

VELOSO, C.M.; RODRIGUEZ, N.M.; SAMPAIO, I.B.M.; GONÇALVES, L.C.; MOURÃO, G.B. pH e amônia ruminais, relação fohas:hastes e degradabilidade ruminal da fibra de forrageiras tropicais, Revista da Sociedade Brasileira de Zootecnia. v. 29, n. 3, p. 871-879, 2000.

VESTERGAARD, M.; THERKILDSEN, M.; HENCKEL,P.; JENSEN, L.R.; ANDERSEN, H.R.; SEJRSEN, K. Influence of feed intensity, grazing and finishing feed on meat and eating quality of young bulls and the relationship between muscle fiber characteristics, fiber fragmentation and meat tenderness. Meat Science, v. 51, n. 1, p. 187-195, 2000.

VIEIRA, P.F.; PEIXOTO, A.M. Recria de bovinos de corte em confinamento e pastagem. In: REUNIÃO ANUAL DA SOCIEDADE BRASILEIRA DE ZOOTECNIA, 13., Salvador, 1976. Anais. Salvador: SBZ. 1976. p. 71-74. 
VILLELA, S.D.J.; VALADARES FILHO, S.C.; SILVA, J.F.C.; CECON, P.R.; LEÃO, M.I.; ALMEIDA, R.G. Caroço de algodão para vacas leiteiras. 3. Efeito na eficiência microbiana, concentração de amônia e pH ruminais. Revista da Sociedade Brasileira de Zootecnia. v. 26, n. 1, p. 195-200, 1997.

WAGNER, D.G.; GILL, D.R.; LUSBY, K.S. Feeding Cattle on Grass. Oaklahoma Cooperative Extension Service. OSU-3014 URL http://www.ansi.okstate.edu/exten/beef. (20 Mar 1998).

WILLMS, W.D.; RODE, L.M.; FREEZE, B.S. Protein supplementation to enhance the performance of pregnant cows on rough fescue grasslands in winter, Canadian Journal of Animal Science, v. 78, n. 1, p. 89-94, 1997.

WING, J. M. Citrus feedstuffs for dairy cattle. University of Florida, Agriculture Experiment Stations, (Bulletin), 1982. 829 p.

WINTER, W. H.; WINKS, L.; SEEBECK, R. M. Sustaining productive pastures in the tropics. Tropical Grassland, v. 25, n. 1, p. 145-156, 1991.

ZERVOUDAKIS, J.T.; PAULINO, M.F.; DETMANN, E.; LANA, R.P.; VALADARES FILHO, S.C.; CECON, P.R., QUEIROZ, D.S.; MOREIRA, A.L. Desempenho e características de carcaça de novilhos suplementados no período das águas. Revista da Sociedade Brasileira de Zootecnia. v. 30, n. 4, p. 11381-1389, 2001. 